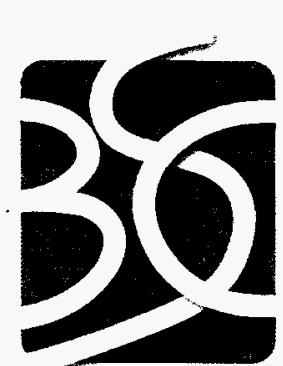

QA: N/A

Page i

000-3YD-EE00-00200-000 REV 002

BECHTEL

SAIC COMPANYLC

June 2004

\title{
Electrical Power System Description Document
}

Prepared for:

U.S. Department of Energy

Office of Civilian Radioactive Waste Management

Office of Repository Development

1551 Hillshire Drive

Las Vegas, Nevada 89134-6321

Prepared by:

Bechtel SAIC Company, LLC

1180 Town Center Drive

Las Vegas, Nevada 89144

Under Contract Number

DE-AC28-01RW12101 


\section{QUALITY ASSURANCE}

The development of this document is not subject to the Quality Assurance Requirements and Description (DOE 2004) requirements. This document was developed in accordance with LP3.26Q-BSC, System Description Documents, which is based on DOE-STD-3024-98, Content of System Design Descriptions.

\section{DISCLAIMER}

This report was prepared as an account of work sponsored by an agency of the United States Government. Neither the United States Government nor any agency thereof, nor any of their employees, nor any of their contractors, subcontractors or their employees, makes any warranty, express or implied, or assumes any legal liability or responsibility for the accuracy, completeness, or any third party's use or the results of such use of any information, apparatus, product, or process disclosed, or represents that its use would not infringe privately owned rights. Reference herein to any specific commercial product, process, or service by trade name, trademark, manufacturer, or otherwise, does not necessarily constitute or imply its endorsement, recommendation, or favoring by the United States Government or any agency thereof or its contractors or subcontractors. The views and opinions of authors expressed herein do not necessarily state or reflect those of the United States Government or any agency thereof 


$$
\begin{array}{l|l|l}
\text { BIC } & \begin{array}{c}
\text { System Description Document } \\
\text { Signature Sheet } \\
\text { Complete only applicable items }
\end{array} & \begin{array}{l}
\text { 1. QA: } \underline{\text { NA }} \\
\text { 2. Page ii of } 48
\end{array}
\end{array}
$$

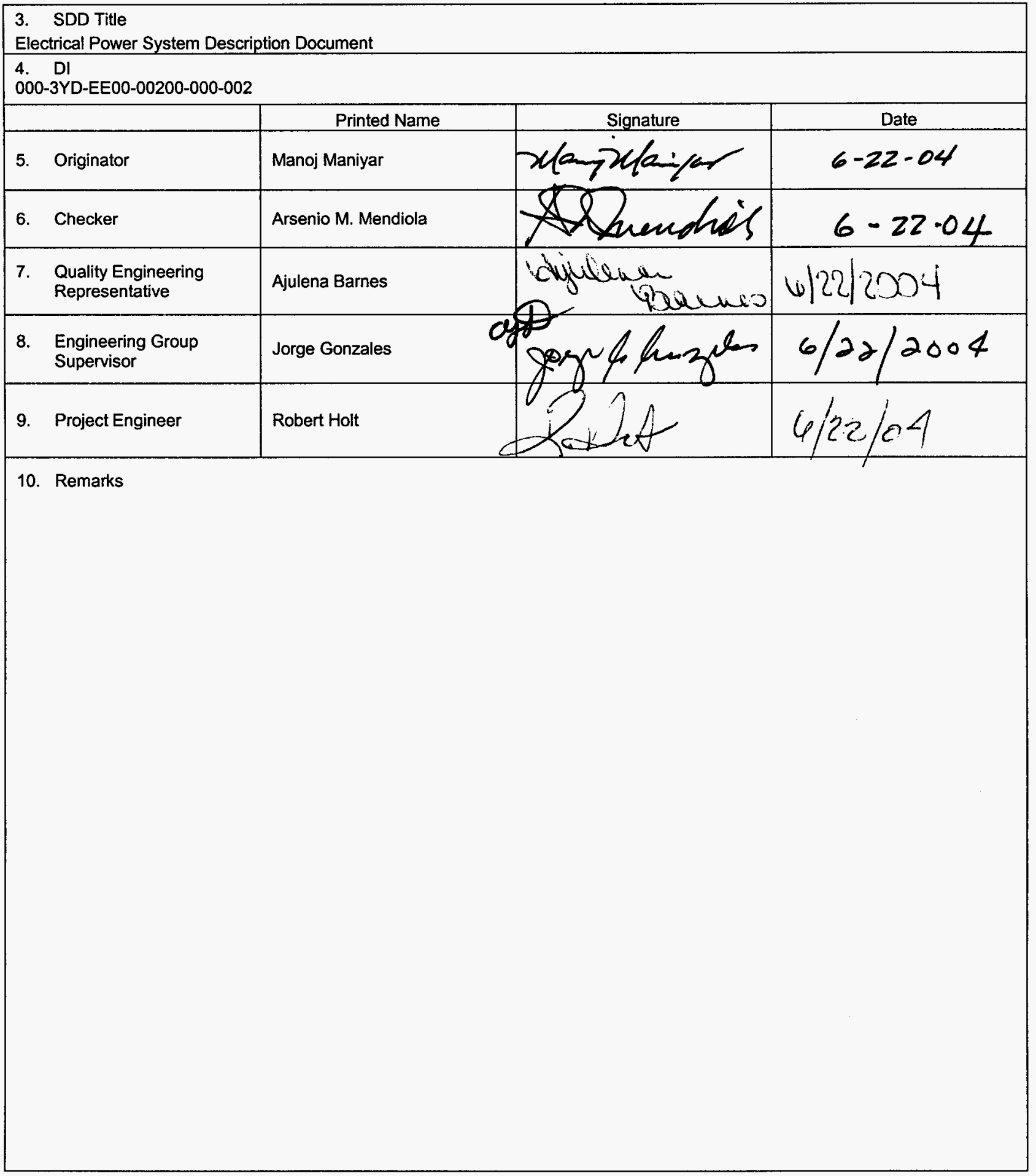




\section{BSC}

\section{System Description Document \\ Change History \\ Complete only applicable items}

11. Page iv of 48

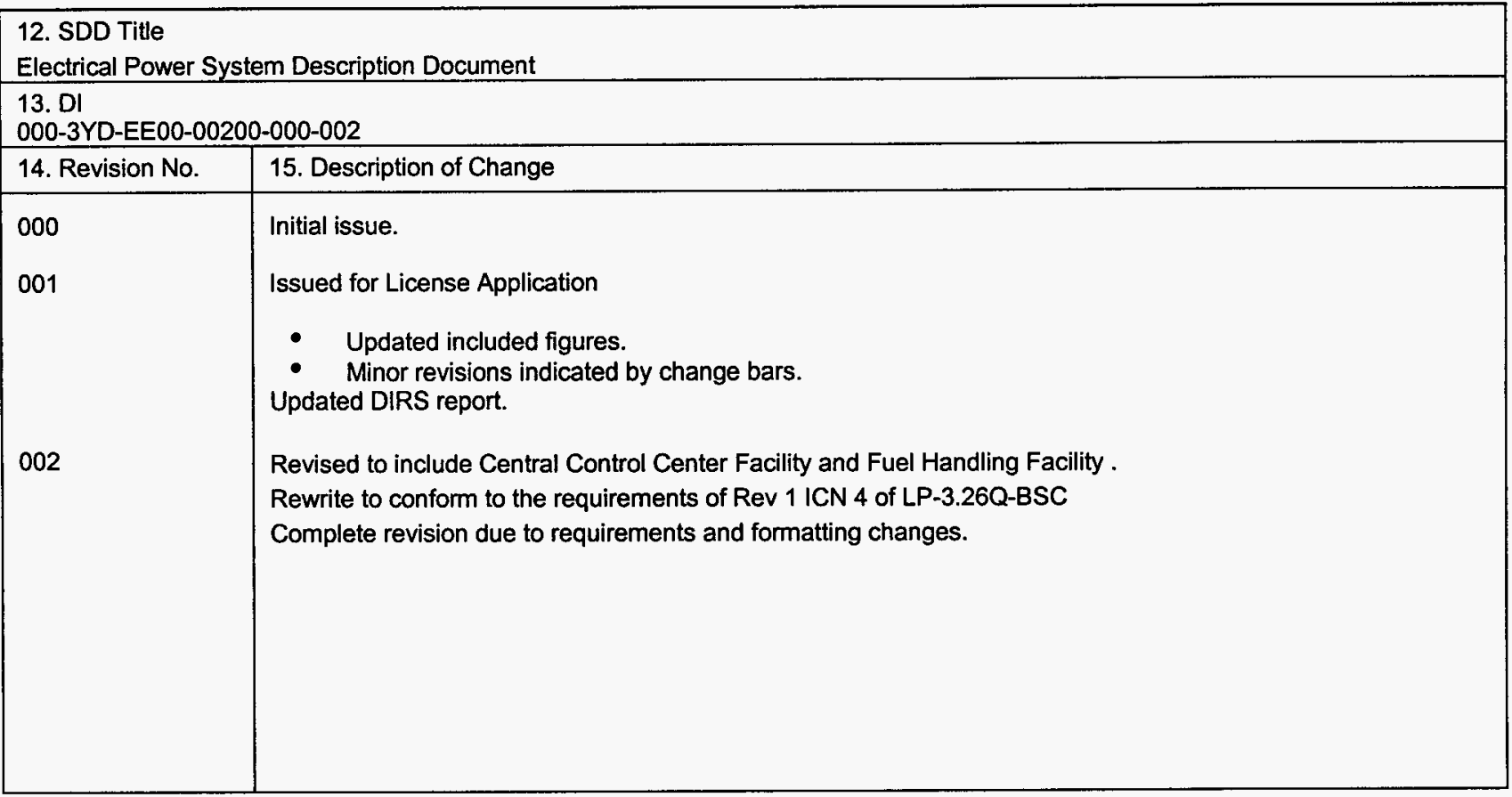


ACRONYMS AND ABBREVIATIONS vii

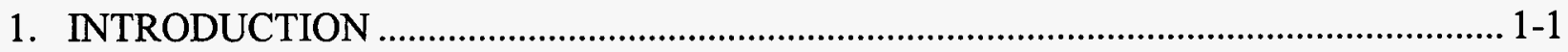

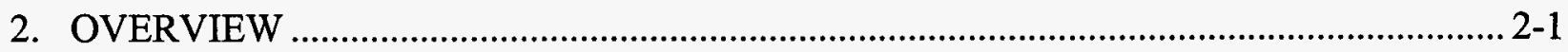

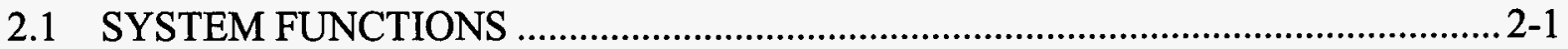

2.2 SYSTEM CLASSIFICATION .................................................................................. 2-1

2.3 OPERATIONAL OVERVIEW ............................................................................. 2-2

3. REQUIREMENTS AND BASES............................................................................. 3-1

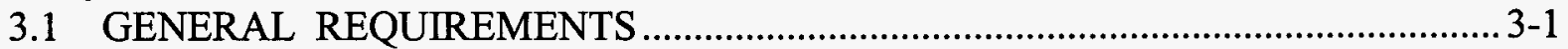

3.2 SPECIAL REQUIREMENTS AND BASES ……................................................

3.3 ENGINEERING DESIGN REQUIREMENTS AND BASES ................................ 3-7

3.4 TESTING AND MAINTENANCE REQUIREMENTS AND BASES ...................... 3-11

3.5 OTHER REQUIREMENTS AND BASES ...................................................... 3-12

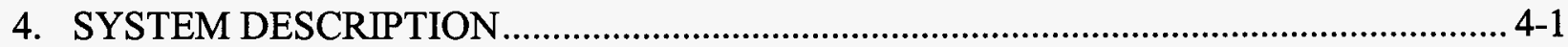

4.1 CONFIGURATION INFORMATION.............................................................. 4-1

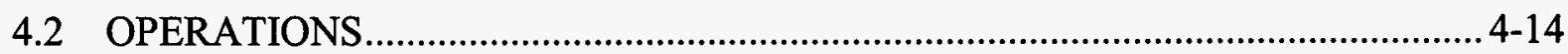

4.3 TESTING AND MAINTENANCE ..................................................................... 4-15

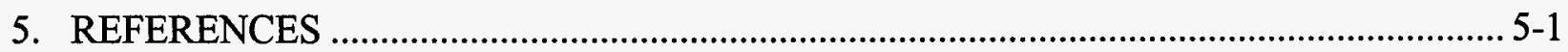

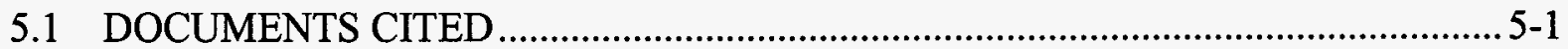

5.2 CODES, STANDARDS, REGULATIONS, AND PROCEDURES ............................. 5-1

5.3 DATA TRACKING NUMBER …………….................................................. 5-2

5.4 SOFTWARE CODES ........................................................................................ 5-2

APPENDIX A: GLOSSARY …

APPENDIX B: LIST OF KEY SYSTEM CHARTS, DIAGRAMS, DRAWINGS, \& LISTS....... B-1 APPENDIX C: LIST OF SYSTEM PROCEDURES C-1 
FIGURES

Figure 2-1 Simplified System Diagram .......................................................................... 2-4

Figure 4-1 Main Single Line Diagram............................................................................ 4-2

Figure 4-2 Switchyard Single Line Diagram $230 \mathrm{kV}$ and $138 \mathrm{kV}$ System ............................... 4-5

Figure 4-3 Single Line Diagram Subsurface Power Distribution............................................. 4-8

Figure 4-4 125VDC System Single Line Diagram.............................................................. 4-9

Figure 4-5 Central Control Center Facility, Communication System Emergency UPS......... 4-10

Figure 4-6 12.47 kV Switchgear Facility and Diesel Generators, Layout Diagram................ 4-13 


\section{ACRONYMS AND ABBREVIATIONS}

\begin{tabular}{|c|c|}
\hline A & amps \\
\hline $\mathrm{AC}$ & alternating current \\
\hline ALARA & as low as is reasonably achievable \\
\hline ANSI & American National Standards Institute \\
\hline BOP & Balance of Plant \\
\hline CCCF & Central Control Center Facility \\
\hline $\mathrm{CHF}$ & Canister Handling Facility \\
\hline CFR & Code of Federal Regulations \\
\hline $\mathrm{DC}$ & direct current \\
\hline DOE & U. S. Department of Energy \\
\hline DTF & Dry transfer facility \\
\hline EDG & Emergency Diesel Generator \\
\hline EMER & Emergency \\
\hline F\&OR & Project Functional and Operational Requirements (Siddoway, 2003) \\
\hline FHF & Fuel Handling Facility \\
\hline GEN & Generator \\
\hline $\mathrm{Hp}$ & horsepower \\
\hline HVAC & heating, ventilating, and air conditioning \\
\hline $\mathrm{Hz}$ & Hertz \\
\hline ITS & important to safety \\
\hline $\mathrm{kV}$ & kilovolts \\
\hline $\mathrm{kW}$ & kilowatt \\
\hline $\mathrm{MCC}$ & motor control center \\
\hline MGR & monitored geologic repository \\
\hline MVA & mega-volt-amperes \\
\hline MW & mega-watts \\
\hline NFPA & National Fire Protection Agency \\
\hline PDC & Project Design Criteria (Doraswamy 2004) \\
\hline PRD & Project Requirements Document (Canori and Leitner 2003) \\
\hline $\mathrm{SC}$ & Safety Category \\
\hline SDD & System Description Document \\
\hline SDG & Standby Diesel Generator \\
\hline SNM & Special Nuclear Material \\
\hline SSC & structure, system, or component \\
\hline SWGR & Switchgear \\
\hline TBD & to be determined \\
\hline TBV & to be verified \\
\hline TSR & Technical Safety Requirement \\
\hline UPS & uninterruptible power supply \\
\hline VAC & Volts - alternating current \\
\hline VDC & Volts - direct current \\
\hline XFMR & Transformer \\
\hline
\end{tabular}




\section{INTRODUCTION}

The purpose of this revision of the System Description Document (SDD) is to establish requirements that drive the design of the electrical power system and their bases to allow the design effort to proceed to License Application. This SDD is a living document that will be revised at strategic points as the design matures over time. This SDD identifies the requirements and describes the system design as they exist at this time, with emphasis on those attributes of the design provided to meet the requirements. This SDD has been developed to be an engineering tool for design control. Accordingly, the primary audience/users are design engineers. This type of SDD leads and follows the design process. It leads the design process with regard to the flow down of upper tier requirements onto the system. Knowledge of these requirements is essential to performing the design process. This SDD follows the design with regard to the description of the system. The description provided in the SDD is a reflection of the results of the design process to date.

Functional and operational requirements applicable to this system are obtained from Project Functional and Operational Requirements (F\&OR) (Siddoway, 2003). Other requirements to support the design process have been taken from higher level requirements documents such as Project Design Criteria Document (PDC) (Doraswamy 2004), the fire hazards analyses, and the preclosure safety analysis. The above mentioned low-level documents address Project Requirements Document (PRD) (Canori and Leitner 2003) requirements.

This SDD includes several appendices with supporting information. Appendix B lists key system charts, diagrams, drawings, and lists; and Appendix $\mathrm{C}$ is a list of system procedures.

\subsection{SYSTEM IDENTIFICATION}

The electrical power system supports the repository facility infrastructure by providing adequate and reliable electric power for construction and operation of all surface facilities and subsurface facilities. The electrical power system consists of the following subsystems: switchyard and standby power subsystem, normal power subsystem, and the emergency power subsystem. A solar power subsystem may be added to the system in the future.

Utility power on two separate transmission lines (one preferred and one alternate) enters the site at the switchyard in the North Portal area. These feeds are stepped down to $12.47 \mathrm{kV}$ by the switchyard power subsystem transformers and sent to the two interconnected $12.47 \mathrm{kV}$ main switchgear buses in the north portal area and two interconnected $12.47 \mathrm{kV}$ main switchgear buses in the south portal area. Standby power consisting of diesel generators can also supply the $12.47 \mathrm{kV}$ switchgear buses if required. From the $12.47 \mathrm{kV}$ main switchgear bus, power is distributed to four normal power $4.16 \mathrm{kV}$ switchgear buses (two in the North Portal area and two in the South Portal area) for further distribution to site facilities and subordinate switchgears. Some individual large loads and ancillary facilities are fed directly from the $12.47 \mathrm{kV}$ main switchgear buses. These buses also supply two $4.16 \mathrm{kV}$ emergency switchgear buses that supply redundant loads for life safety and egress functions. The emergency switchgear buses can be supplied from connected Emergency Diesel Generators if needed. 
The electrical power system interfaces with all surface facilities and the subsurface facility. The electrical power system also interfaces with the electrical support system. The electrical support system consists of the following subsystems:

- Lighting

- Grounding

- Lightning protection

- Cathodic protection

- Heat tracing

- Cable raceway (including underground ducts).

\subsection{LIMITATIONS OF THIS SYSTEM DESCRIPTION DOCUMENT}

As noted above, the electrical power system interfaces with the electrical support system, which is described in a separate SDD.

This SDD may include assumptions, preliminary information, and "to be verified"(TBV) values, as appropriate to the current level of design development. Additionally, requirements or descriptions that are stated as "to be determined" (TBD) or are expected at a later phase of the design will be described as such.

At the time of the approval of this version, the status of the design is that the conceptual design has been completed and the Title I preliminary design has been started. As the necessary design documents (calculations, drawings, specifications, and other supporting documents) are completed, the description of the system design will be updated.

\subsection{OWNERSHIP OF THIS SYSTEM DESCRIPTION DOCUMENT}

This electrical power system SDD is owned by the Electrical and Control Systems group of Design and Engineering. 


\section{OVERVIEW}

\subsection{SYSTEM FUNCTIONS}

The electrical power system is described as follows in Section 1.4.1.2.2 of the F\&OR (Siddoway, 2003):

"The MGR[repository] shall be provided with adequate and reliable electrical power supplies from transmission lines of the electric utility company and automatic switchyard switching through main transformers for power distribution in the MGR[repository]. The offsite power from the utility transmission line shall be the normal power for the MGR[repository]. The onsite standby and emergency diesel generators shall supply electrical power to the MGR[repository] upon loss of offsite power."

System functional requirements from the F\&OR are contained in the subsection titles. The implementing performance requirements and operational requirements are described in each subsection along with the section of the F\&OR from which they are taken.

\subsubsection{Receive and Distribute Adequate and Reliable Electrical Power}

Commercially available power shall be provided to meet an MGR[repository] power demand during construction and operations. $\{\mathrm{F} \& \mathrm{OR}$ 1.4.1.2.2-1\}

\subsubsection{Provide A Solar Power System to Augment Commercially Available Power}

A $3 \mathrm{MW}$ solar power system shall be used in conjunction with commercially available power. $\{\mathrm{F} \& \mathrm{OR}$ 1.4.1.2.2-2\}

The solar power system is on hold and is not further described in this SDD.

\subsubsection{Provide Emergency Power}

The functional requirement from the F\&OR is that during loss of primary power, a reliable and timely emergency power system shall supply necessary monitoring and operating power.

The operational and performance requirement is that the MGR[repository] shall ensure uninterrupted AC/DC power to instruments, facility service systems, important-to-safety (ITS) operating systems, and to selected non-ITS systems. \{F\&OR 1.4.1.2.2-3\}

\subsection{SYSTEM CLASSIFICATION}

This system consists of no structure, system or components (SSCs) important to safety or natural and engineered barriers important to waste isolation. This system is in the non-safety category (non-SC) and not the subject of the facilities operational or technical safety requirements (TSR). 
Additional information regarding system classification maybe found in Q-List (BSC 2003a), Safety Classification of SSCs and Barriers (BSC 2004c), and/or Preliminary Nuclear Safety Design Bases for License Application (BSC 2003c).

\subsection{OPERATIONAL OVERVIEW}

Figure 2-1 is a simplified system drawing that shows the relationship of the switchyard and standby power subsystem, normal power distribution subsystem and emergency power subsystem.

The switchyard is located at the southwest corner of the North Portal Facility area and receives power via $230 \mathrm{kV}$ (preferred) and $138 \mathrm{kV}$ (alternate) overhead transmission lines from the electrical power utility company. Power can be transferred from one source to the other through breaker controls. This power is stepped down to $12.47 \mathrm{kV}$ by transformers in the switchyard and further distributed to the site through $4.16 \mathrm{kV}$ switchgear buses in the $4.16 \mathrm{kV}$ Switchgear Facility. There are several direct connected loads on the $12.47 \mathrm{kV}$ main switchgear buses.

The standby power portion of the switchyard and standby power subsystem consists of four Standby Diesel Generators (SDGs), two for each $12.47 \mathrm{kV}$ main switchgear buses A and B. These are housed in the Standby Diesel Generator facility near the switchyard. The SDGs supply loads should both the preferred and alternate utility supplies fail. The loads that are supplied by the SDGs shall be determined in detail as the design matures.

The normal power subsystem distributes power from the $12.47 \mathrm{kV}$ main switchgear buses via cables in underground duct banks to North Portal facilities and to the South Portal facilities via an overhead transmission line. Normal power is also provided via overhead transmission lines to the North Construction area, and shaft ventilation areas. Normal power is stepped down to 4.16 $\mathrm{kV}$ by transformers and distributed to repository facilities in the North Portal area via underground duct banks. Inside each facility, step-down transformers are provided for low voltage distribution by load centers, motor control centers, power panels, instrument panels, and control panels as required.

Power needed in the South Portal area is distributed from the South Portal $12.47 \mathrm{kV}$ Main Switchgear facility. The North and South Portal $12.47 \mathrm{kV}$ switchgear facilities each contain two switchgear. Normal power electrical loads are designated as A or B to balance the loading on the system. The A and B normal power switchgears are provided with tiebreakers that permit connecting them together should this be necessary. The normal power subsystem also provides battery-backed, $120 \mathrm{VAC}$ uninterruptible power supply (UPS) power for required loads (TBD). The 125 VDC system provides power for breaker control, protective relaying, and other required loads. A $125 \mathrm{VDC}$ battery provides backup power to the normal $125 \mathrm{VDC}$ loads.

The emergency power subsystem supplies loads essential for safety of human life, as defined in article 700 of the NFPA 70, National Electrical Code and IEEE Std 446-1995, IEEE Recommended Practice for Emergency and Standby Power Systems for Industrial and Commercial Applications. The loads supplied by emergency power are: post-event monitoring system, communications, egress lighting in defined areas, limited select HVAC units, and worker 
industrial and life safety. The specific loads fed from emergency power shall be determined as the design progresses.

Emergency power is distributed to required loads from two $4.16 \mathrm{kV}$ emergency switchgear buses that are physically and electrically separated and are located in the North Portal $4.16 \mathrm{kV}$

Switchgear facility. The normal supply to the $4.16 \mathrm{kV}$ emergency switchgear buses are from the $12.47 \mathrm{kV}$ main switchgear buses. One emergency diesel generator (EDG) shall supply each 4.16 $\mathrm{kV}$ emergency switchgear bus, if the normal supply is lost. The number of hours of continuous operation provided by the integral fuel oil tank for each diesel will be determined as design matures. Some emergency power loads are supplied from battery backed UPS, which shall maintain power until the EDGs are up to full speed and voltage. 


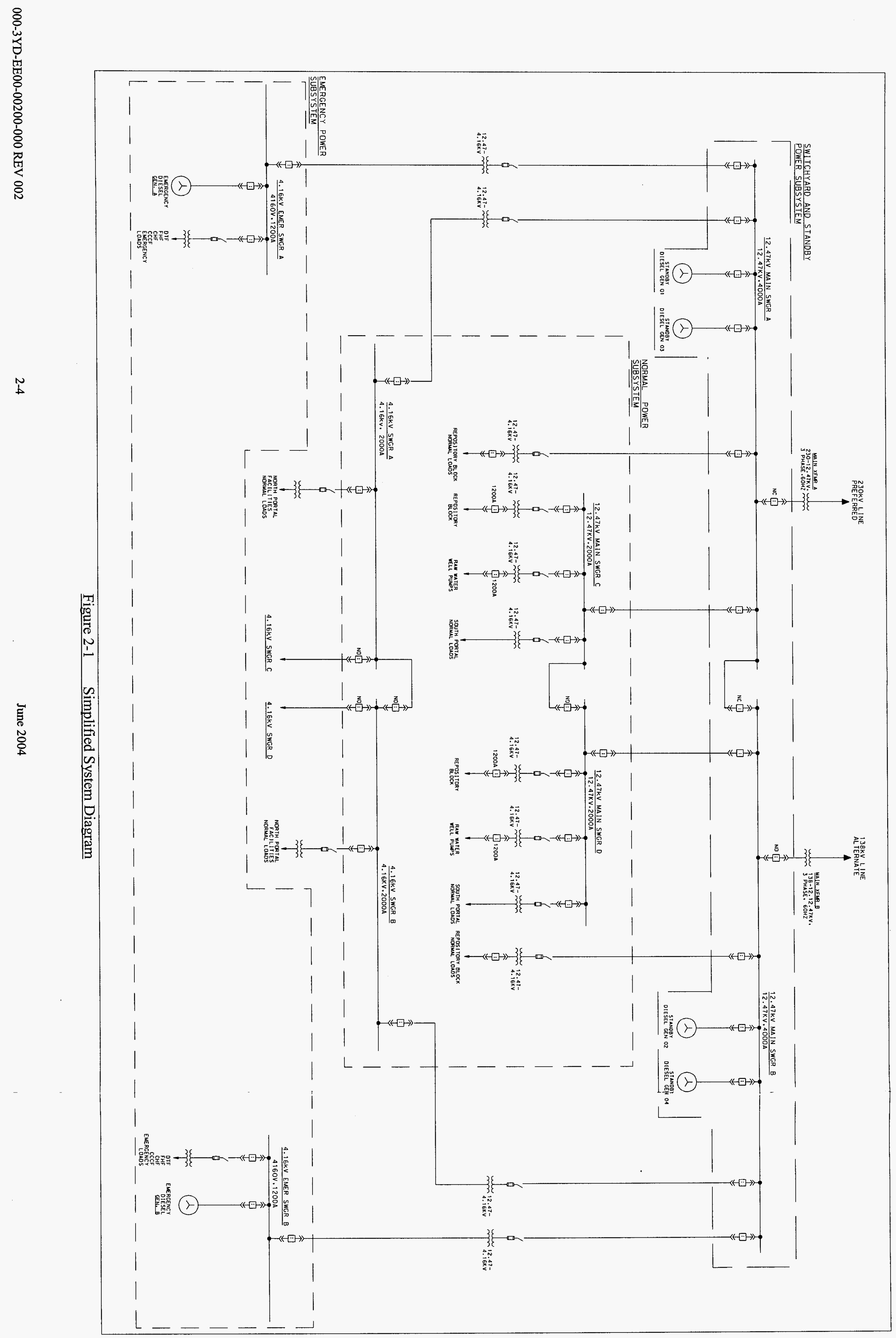




\section{REQUIREMENTS AND BASES}

All requirements referencing Preliminary Nuclear Safety Design Bases for License Application (BSC 2003c) are classified as 10 CFR Part 63 requirements and are located in Section 3.1.1.1. The remaining requirements and associated bases are classified as External Compliance unless noted within the appropriate comment section.

\subsection{GENERAL REQUIREMENTS}

\subsubsection{SYSTEM FUNCTIONAL REQUIREMENTS}

\subsubsection{Safety Requirements}

Not Applicable - The electrical power system is non-SC.

\subsubsection{Environmental Requirements}

No environmental requirements for the system have been identified at this stage of the design. Environmental requirements for the following activities may be developed in the future and shall be applied as needed.

Land disturbance from transmission line towers Noise and emission controls for the system's diesel generators Requirements for the on-site storage and handling of diesel generator fuel oil

There are several environmental requirements that limit total site land disturbance, water usage and air emissions. These have not been subdivided and allocated to individual facilities or systems; however, it is necessary in the design of each facility or system to predict the impact of facility/system construction and operation on these elements. A requirement for this has been included below:

\subsubsection{Mission-Critical Requirements}

3.1.1.3.1 Requirement: The Yucca Mountain Project (YMP) power systems shall be divided into switchyard and standby power, normal power and emergency power subsystems. Uninterruptible and DC power sources shall be included for selected power and control functions. Supports Function 2.1.1.

Basis: The repository normal, standby and emergency power subsystems were selected based on NFPA 70 . [PDC 4.3.1.1.4]

3.1.1.3.2 Requirement: The switchyard located at the southwest corner of the North Portal facility area shall be used to receive power via $230 \mathrm{kV}$ and $138 \mathrm{kV}$ overhead transmission lines from the utility power company. Supports Function 2.1.1.

Basis: This requirement establishes the criteria for utility power supply to the site and establishes the interface point with the electrical power system. [PDC 4.3.3.1] 
3.1.1.3.3 Requirement: The $230 \mathrm{kV}$ and $138 \mathrm{kV}$ power at the switchyard shall be stepped down to $12.47 \mathrm{kV}$ by means of a step-down transformer located in the switchyard. The $230-12.47 \mathrm{kV}$ step down transformer shall be the primary main transformer; it shall supply all facility loads normally. The 138-12.47 kV step down transformer shall be the alternate main transformer; it shall supply certain facility loads when the primary main transformer is not available. Supports Function 2.1.1.

Basis: This requirement defines the roles of the two main step down transformers and sets primary site voltage in accordance with good engineering practice. [PDC 4.3.3.3 and PDC 4.3.3.4]

3.1.1.3.4 Requirement: The system design shall provide a 30 percent margin to accommodate future load growth. Supports Function 2.1.1.

Basis: This requirement is needed to ensure that the electrical system is designed with sufficient margin for the future. The value of 30 percent is based on engineering judgment derived from standard engineering practice regarding system margins. The 30 percent value is applied in addition to the system loads defined during the final design. [PDC 4.3.1.1.2]

3.1.1.3.5 Requirement: The system shall regulate the utilization voltage to plus or minus 10 percent. Supports Function 2.1.1.

Basis: This requirement defines the capability of the electrical power system to supply power for the end item equipment. This voltage drop limit is for normal operations because a momentary voltage drop shall occur for the starting of large motors. This value is in line with IEEE Std 141-1993, IEEE Recommended Practice for Electrical Power Distribution for Industrial Plants, and ANSI C84.1-1995, Electrical power systems and Requirements. [PDC 4.3.1.1.3]

3.1.1.3.6 Requirement: The facility normal power supply voltages shall be $12.47 \mathrm{kV}, 4.16 \mathrm{kV}$, $480 \mathrm{~V}$, for 3-phase and $277 \mathrm{~V}, 208 \mathrm{~V}, 120 \mathrm{~V}$, for single phase, $60 \mathrm{~Hz}$ for AC system. The allowable frequency variation will be determined as the design matures. The DC battery system voltage shall be 125 V. Supports Function 2.1.1.

Basis: This requirement defines the facility application voltages, per IEEE Std 141-1993, IEEE Recommended Practice for Electrical Power Distribution for Industrial Plants. These voltages are most commonly used in the industry in the United States for medium and low voltage systems. Electrical equipment is most readily available in these voltages and has proven performance. The specification of system voltages that shall be available permits the design of process systems to proceed with certainty with regards to power supply. The medium voltage $12.47 \mathrm{kV}$ is currently used in the existing system at the site, therefore it is selected over $13.8 \mathrm{kV}$ system for the sake of service continuity. [PDC 4.3.1.1.5]

3.1.1.3.7 Requirement: The facility emergency power supply voltages shall be $4.16 \mathrm{kV}, 480 \mathrm{~V}$, for 3-phase and $277 \mathrm{~V}, 208 \mathrm{~V}, 120 \mathrm{~V}$, for single phase, $60 \mathrm{~Hz}$ for AC system. The emergency DC battery system voltage shall be $125 \mathrm{~V}$. Supports Function 2.1.3.

Basis: This requirement defines the facility application voltages, per IEEE Std 141-1993, IEEE Recommended Practice for Electrical Power Distribution for Industrial Plants. These voltages are most commonly used in the industry in the United States for medium and low voltage systems. Electrical equipment is most readily available in these voltages and has proven performance. The specification of system voltages that shall be available permits the design of process systems to proceed with certainty with regards to power supply. [PDC 4.3.2.1] 
3.1.1.3.8 Requirement: The standby diesel generators shall be rated $12.47 \mathrm{kV}$ and the emergency diesel generators shall be rated $4.16 \mathrm{kV}, 3$-phase and $60 \mathrm{~Hz}$, wye connected. Upon loss of off-site power, the diesel generators shall be automatically started. Supports Functions 2.1.1 and 2.1.3.

Basis: This requirement defines optimum system design. The standby power voltage requirement is based on minimizing the impact of the remote locations of the standby loads. Because the location of "emergency" equipment loads is local to the North Portal, the emergency diesel generator can be rated at a lower voltage. [PDC 4.3.1.1.21]

3.1.1.3.9 Requirement: The UPS shall be provided to supply critical power of acceptable quality, without delay or transient during a power interruption, to important monitoring and control loads that cannot tolerate a power interruption. The UPS shall also supply important computer systems. Supports Function 2.1.1.

Basis: This requirement is in accordance with IEEE Std 446-1995, Emergency and Standby Power System for Industrial and Commercial Applications. [PDC 4.3.1.1.19]

3.1.1.3.10 Requirement: The UPS system for facility control and instrumentation applications shall be supplied by 480 VAC power and the output shall be $208 / 120 \mathrm{~V}$, 3-phase, $60 \mathrm{~Hz}$. The UPS battery banks shall be sized to provide full UPS rated load. Supports Functions 2.1.1.

Basis: This requirement is required to define the UPS system voltage. The selected voltage is most commonly used in the industry. The minimum continuous UPS operating time is required to assure nuclear safety for facility operation during a loss of offsite power. The requirement of providing uninterruptible power is also indicated in NFPA 70, National Electrical Code [PDC 4.3.1.1.20]

3.1.1.3.11 Requirement: The nominal voltage of the DC battery system shall be 125 VDC. The battery system shall be designed for a long life and low maintenance requirements. The $480 \mathrm{~V}$ supply for the battery charger for the DC power system shall be from a motor control center. Supports Functions 2.1.1.

Basis: This requirement defines the DC system voltage. The voltage is most commonly used in the industry. The performance and reliability are superior. Battery with long life and low maintenance type shall be required. The minimum battery discharge time is required to assure a continuous power supply during a loss of offsite power. This is important for a safe facility operation and shutdown by providing sufficient backup power. This is in accordance with NFPA 70, National Electrical Code. [PDC 4.3.1.1.18]

\subsubsection{General Requirements}

3.1.1.4.1 Requirement: All facility electrical loads shall be designated as either group A or group B. Each group receives power from one of two $12.47 \mathrm{kV}$ main switchgears A and B. The loads shall be distributed, as much as possible, to achieve balance between groups. Supports Function 2.1.1.

Basis: This requirement defines the power distribution system structure. This simplifies the system design, system control, and improves reliability. Division of the loads can also facilitate maintenance and increase availability of the facility loads. Division of loads is in accordance with good engineering practices. [PDC 4.3.1.1.7] 
Electrical Power System Description Document

3.1.1.4.2 Requirement: The switchyard shall be fenced and the access gate shall be locked to limit the access to only qualified workers. Supports Function 2.1.1.

Basis: This criterion is required to protect the safety of non-job-related personnel, as required in the NFPA 70, National Electrical Code. This is also a common industry practice. [PDC 4.3.3.2]

\subsubsection{Subsystem and Major Components}

System-level requirements for the standby and emergency diesel generators are described above.

3.1.2.1 Requirement: The normal UPS power to the welding equipment for waste package closure shall have sufficient capacity to supply power for at least 15 minutes after loss of normal and standby power. Supports Function 2.1.3.

Basis: This requirement assures that an in-process waste package can be placed in a safe condition (welded closed) should a loss of power occur. [Operational Constraint]

\subsubsection{Boundaries and Interfaces}

The requirement for the electrical power system boundary between utility power and site power is discussed in the system-level requirement for the utility supply and system power factor. There are no other system boundary requirements that must be accounted for in the design of the system.

The electrical power system interfaces with all facilities and their housed systems to provide power. The requirements for voltage regulation and supplied voltages are included in the system-level requirements above.

The electrical power system interfaces with the Electrical Power Support System. The latter system provides requirements for support elements such as grounding, cable separation, ductbanks and raceways, and lightning protection. The requirements for these support functions are contained in the Electrical Support System SDD.

\subsubsection{Codes, Standards, and Regulations}

Codes, standards, and regulations that apply to the electrical power system are contained in the PDC (Doraswamy 2004) in the following sections.

Section 4.3.1 - general design criteria

Section 4.3.2 - emergency electrical power design criteria

Section 4.3.3 - switchyard and transmission design criteria

Section 4.3.4 - normal electrical power design criteria

Section 4.9.3.1 - As Low As Reasonably Achievable (ALARA) codes and standards 


\subsubsection{Operability}

The electrical power system is highly reliable but is not required to be operational to mitigate Category 1 or 2 event sequences. Consequently, the electrical power system is categorized as non-safety category SSC.

\subsection{SPECIAL REQUIREMENTS AND BASES}

Hazard analyses are not yet complete but are assumed to be potentially applicable. This section will be updated for each hazard with information on applicability/non-applicability, mitigating and/or fail safe performance requirements, environments, monitoring, alarms, and interfaces. See Preliminary Hazards Analysis for License Application Study (BSC 2004b) for additional information.

\subsubsection{Radiation and Other Hazards}

3.2.1.1 Requirement: The system components shall be hardened or properly shielded to withstand and operate under the radiation levels in which they are installed commensurate with the performance basis of the equipment. Supports Function 2.1.1.

Basis: The requirement ensures that the system components will perform their intended functions. [PDC 4.9.3.5]

\subsubsection{ALARA}

3.2.2.1 Requirement: The electrical power system shall be located and/or shielded to minimize exposure to meet ALARA principles. Supports Function 2.1.1.

Basis: This requirement will minimize personnel exposure. [PDC 4.9.3.3]

\subsubsection{Nuclear Criticality Safety}

3.2.3.1 Requirement: The electrical power system shall be designed so that it shall not initiate any credible criticality event. Supports Function 2.1.1.

Comment: The electrical power system performance requirements shall be ascertained from the review to prevent the hazards of a criticality event.

Basis: Nuclear facility safety standards seek to prevent unplanned nuclear criticality events and protect workers and environment from potentially harmful exposures. This requirement will ensure that this goal is met. [PDC 4.9.2.2.1]

\subsubsection{Industrial Hazards}

No industrial hazards have been identified at this time. As the design matures, requirements for addressing industrial hazards shall be established as needed.

\subsubsection{Operating Environment and Natural Phenomena}

\subsubsection{Normal Environment}


3.2.5.1.1 Requirement: Equipment shall be designed for the applicable environmental conditions. Supports Function 2.1.1.

Basis: This requirement is based on good engineering practice. [PDC 6.1.1]

3.2.5.1.2 Requirement: The design of the system shall account for the effects of the site altitude on equipment performance. Supports Function 2.1.1.

Basis: This requirement is based on good engineering practice. [Operational Constraint]

\subsubsection{Earthquake}

3.2.5.2.1 Requirement: All equipment in the emergency power sub-system shall be designed for the 1,000 year earthquake. Acceptability of passive equipment such as cable tray and supports shall be verified by analysis. Acceptability, including operability after an earthquake, for active equipment such as diesel generators, switchgear, and related power distribution equipment shall be verified in accordance with ANSI/IEEE Std 344-1987, Section 9. Supports Function 2.1.3.

Basis: This requirement is to ensure that the emergency power subsystem is available after a seismic event. [Preliminary Hazards Analysis for License Application Study (BSC 2004b)]

\subsubsection{Tornado, Extreme Winds, Rainstorm}

3.2.5.3.1: Requirement: Emergency power equipment shall be designed and/or protected to maintain operability in the event of a tornado or extreme winds. The emergency diesel generators shall include provisions that assure that intake air quality is not compromised by outside ambient conditions, which may arise during normal, off-normal, or emergency conditions caused by rainstorms, high winds, sandstorms, tornadoes or high dust loading. Supports Function 2.1.3.

Basis: This requirement is to ensure that emergency power equipment is available after a tornado, extreme winds or a rainstorm. [Preliminary Hazards Analysis for License Application Study (BSC 2004b)].

Comment: Volcanic ash fall shall be addressed at a later date as no information is available to quantify requirements at this time.

\subsubsection{Flooding}

3.2.5.4.1 Requirement: Emergency power equipment shall be installed in a manner that will prevent any impact due to flooding. Supports Function 2.1.3.

Basis: This requirement is necessary to prevent damage to equipment due to flooding. [Preliminary Hazards Analysis for License Application Study (BSC 2004b)]

\subsubsection{Loss of Offsite Power}

3.2.5.5.1 Requirement: The emergency power system shall be designed to be operable during periods of loss of offsite power. Supports Function 2.1.3. 
Basis: This requirement is based on the YMP Hazards Analysis for License Application, [Preliminary Hazards Analysis for License Application Study (BSC 2004b)]

\subsubsection{Human Interface Requirements}

The electrical power system is non-SC. Currently, there are no design requirements for alarms intended to trigger manual safety actions. Therefore there are no human interface requirements for the system design. As system design evolves and system operations documents are developed, design requirements to assure appropriate human interface with the system may be needed.

\subsubsection{Specific Commitments}

3.2.7.1 Requirement: The emergency power system shall be designed and operated to meet pollution prevention and sustainable design and decommissioning goals. Supports Function 2.1.3.

Basis: The electrical power system shall meet the requirements of pollution prevention and sustainable design and decommissioning goals. [PDC 4.2.3.3.8 \& PDC 4.8.4.3.1]

3.2.7.2 Requirement: The repository shall be designed with pollution prevention systems to control air emissions and effluents, minimize water use, and reduce or eliminate discharges to the environment. Supports Function 2.1.1.

Basis: The design shall comply with applicable environmental requirements set forth by federal and state regulations, Executive Orders, and DOE Directives, and requirements derived from environmental permits and corresponding permit conditions. [PDC 4.1.1.9]

\subsection{ENGINEERING DESIGN REQUIREMENTS AND BASES}

\subsubsection{Civil and Structural}

The electrical power system does not currently have any specific civil and structural requirements. For seismic requirements refer to Section 3.2.5.2.

\subsubsection{Mechanical and Materials}

The switchyard, standby power, and normal power sub-systems of the electrical power system are comprised of standard, commercial grade components and no special design requirements are needed for mechanical or material engineering of these sub-systems.

\subsubsection{Chemical and Process}

There are no chemical and process requirements for the design of the electrical power system. 


\subsubsection{Electrical Power}

3.3.4.1 Requirement: All electrical equipment, raceways, and cables of the YMP Facility shall be given unique identification numbers, except for lightning protection, cathodic protection, and grounding systems. Furthermore, parts of the lighting system and heat trace system shall also take exception to this requirement. Supports Function 2.1.1.

Basis: This requirement is based on good engineering practice. [PDC 4.3.1.1.8]

3.3.4.2 Requirement: Transformers shall be liquid-filled for outdoor service and dry-type for indoor service. Supports Function 2.1.1.

Basis: This requirement is based on good engineering practice. [PDC 4.3.1.1.9]

3.3.4.3 Requirement: The transformers for outdoor installation shall be $230 \mathrm{kV}$ to $12.47 \mathrm{kV}$, $138 \mathrm{kV}$ to $12.47 \mathrm{kV}, 12.47 \mathrm{kV}$ to $4.16 \mathrm{kV}, 12.47 \mathrm{kV}$ to $480 / 277 \mathrm{~V}, 4.16 \mathrm{kV}$ to $480 / 277 \mathrm{~V}$, and $480 \mathrm{~V}$ to $208 / 120 \mathrm{~V}$. The transformer shall be 3-phase, $60 \mathrm{~Hz}$, with no-load manually operated taps. The primary side shall be delta connected. The secondary side shall be wye connected with the neutral resistance-grounded for $4.16 \mathrm{kV}$ secondary and solid grounded for $480 \mathrm{~V}$ secondary. Supports Function 2.1.1.

Basis: This requirement standardizes design for reliable operation. The transformers with these voltages are most commonly used in the industry. The neutral resistance grounding in the medium voltage system shall minimize the fault current for human safety. The solid neutral grounding for low voltage system will facilitate quick clearing of fault. The delta-wye connection will minimize grounding fault effects and minimize harmonics in the system. [PDC 4.3.1.1.10]

3.3.4.4 Requirement: The medium voltage switchgears shall be rated at $12.47 \mathrm{kV}$ or $4.16 \mathrm{kV}, 3$ phase, $60 \mathrm{~Hz}$. The switchgears shall be rated to withstand the maximum short-circuit current available in the system. Supports Function 2.1.1.

Basis: This requirement defines the system operating voltages to standardize design. The maximum short-circuit current withstanding capability is required for protection of personnel safety, equipment and system protection and is in accordance with standard industrial practice. [PDC 4.3.1.1.11]

3.3.4.5 Requirement: Lighting and instrumentation transformers shall be dry type (except outdoor application). The primary side shall be delta connected, the secondary side shall be wye connected and the neutral solidly grounded (secondary voltages shall be $480 / 277 \mathrm{~V}$ or 208/120V). Supports Function 2.1.1.

Basis: This requirement is based on good engineering practice. It will minimize fire hazards by not using oil-filled transformers for indoor application, and minimize harmonics in the system. [PDC 4.3.1.1.12]

3.3.4.6 Requirement: $480 \mathrm{~V}$ load centers shall be used to provide power to the downstream motor control centers, motors larger than $150 \mathrm{hp}$ up to $300 \mathrm{hp}$, and static loads up to $400 \mathrm{~kW}$. Supports Function 2.1.1.

Basis: This requirement is based on standard industry practice. This practice will minimize the stress in electrical equipment. This will enhance long-term operation of the equipment. [PDC 4.3.1.1.13] 
3.3.4.7 Requirement: $480 \mathrm{~V}$ motor control centers (MCC) shall be used to provide AC power to induction motors and other loads rated above1/3 hp and up to $150 \mathrm{hp}$, and miscellaneous branch circuits. Static (resistive) loads up to $240 \mathrm{~kW}$ can be served from MCCs. Supports Function 2.1.1.

Basis: This requirement is based on standard industry practice. This practice will facilitate easy installation and easy replacement of motors or static loads. [PDC 4.3.1.1.14]

3.3.4.8 Requirement: In general, $\mathrm{AC}$ motors shall be squirrel-cage, induction type, suitable for operation from the following supplies:

$\begin{array}{ll}\text { Motor Size } & \text { Utilization Voltage } \\ {\text { and smaller }} } & 115 \mathrm{~V} \\ 1 / 2 \mathrm{hp} \text { to } 300 \mathrm{hp} & 460 \mathrm{~V} \\ 300 \mathrm{hp} \text { to } 7,500 \mathrm{hp} & 4 \mathrm{kV}\end{array}$

System Supply
$120 \mathrm{~V}, 1$-phase, $60 \mathrm{~Hz}$
$480 \mathrm{~V}, 3$-phase, $60 \mathrm{~Hz}$
$4.16 \mathrm{kV}, 3$-phase, $60 \mathrm{~Hz}$

Supports Function 2.1.1.

Basis: This requirement is based on standard industry practice such as suggested in IEEE Std 141-1993 and ANSI Std C84.1-1995. [PDC 4.3.1.1.15]

3.3.4.9 Requirement: The motors used for outdoor installation or in the hazard location shall be either totally enclosed fan-cooled (TEFC), totally enclosed non-ventilated (TENV), or weatherprotected, type II (WP II). Supports Function 2.1.1.

Basis: This requirement is required to ensure that the motor is protected from weather or chemical hazards [PDC 4.3.1.1.16]

3.3.4.10 Requirement: Variable speed drive shall be used where it is required to control speed of the driven mechanical equipment. Supports Function 2.1.1.

Basis: This requirement is based on good engineering practice. [PDC 4.3.1.1.17]

3.3.4.11 Requirement: The $15 \mathrm{kV}$ and $5 \mathrm{kV}$ power cable shall be single conductor or triplexed Class B stranded copper conductor, 133 percent insulation level and rated for continuous operation at $90^{\circ} \mathrm{C}\left(194^{\circ} \mathrm{F}\right), 130^{\circ} \mathrm{C}\left(266^{\circ} \mathrm{F}\right)$ for emergency overload operation and $250^{\circ} \mathrm{C}\left(482^{\circ} \mathrm{F}\right)$ for short circuit conditions. Supports Function 2.1.1.

Basis: This requirement assures the quality of cables to be satisfactory for normal and emergency applications. [PDC 4.3.1.3.1]

3.3.4.12 Requirement: The power, lighting, motor feeder and control cables shall be single conductor or multi-conductors, copper, rated $600 \mathrm{~V}, 75^{\circ} \mathrm{C}\left(167^{\circ} \mathrm{F}\right)$. The conductor shall be harddrawn copper. All power and control wiring shall be standard copper flame-retardant moisture and heat-resistant or heat-resistant thermoplastic insulated $75^{\circ} \mathrm{C}\left(167^{\circ} \mathrm{F}\right)$. Supports Function 2.1.1. 
Basis: This requirement assures the quality of cables to be satisfactory for normal and emergency applications. [PDC 4.3.1.3.2]

3.3.4.13 Requirement: Power cables of size $\# 2 / 0$ and larger shall be single conductor or triplexed. Cables for lighting circuits shall be single conductor, solid copper. Cable insulation and jacket material shall be resistant to heat, moisture, impact, radiation (where required) and ozone. Supports Function 2.1.1.

Basis: This requirement assures the quality of cables to be satisfactory for normal and emergency applications. [PDC 4.3.1.3.3]

3.3.4.14 Requirement: All lighting and receptacle panel branch circuits shall have a maximum of three circuits sharing a common neutral for single-phase loads. Where non-linear loads have been identified, the neutral shall be sized accordingly. Supports Function 2.1.1.

Basis: This requirement limits the ground fault current passing through a neutral conductor, to maintain the integrity of the circuit. This is in accordance with the requirements of NFPA 70, National Electrical Code Article 250. [PDC 4.3.1.3.4]

3.3.4.15 Requirement: Instrument cables shall be single-pair, triad-twisted and shielded, or multi-pair with shielded pair and overall shield with a drain wire, unless supplied by the instrument vendor. Supports Function 2.1.1.

Basis: This requirement provides the capability to shield the instrument signals from noise transmitted on to the cable, in order to prevent instrument malfunction due to the noises in the instrumentation cable. [PDC 4.3.1.3.5]

3.3.4.16 Requirement: All instrument cable shall be fire-resistant. All instrument wiring shall be stranded. Fiber optic cable and field-bus shall be used for most data network, voice and video communication. Supports Function 2.1.1.

Basis: This requirement assures the satisfactory performance of cables with the state-of-the-art technologies. This will ensure integrity of instrumentation system function. [PDC 4.3.1.3.6]

3.3.4.17 Requirement: All cable insulation and jacket material shall be of low flammability type. Supports Function 2.1.1.

Basis: This requirement is required to protect cables from failure due to fire or heat. Cable testing shall be in accordance with IEEE Std 1202-1991, IEEE Standard for Flame Testing of Cables for Use in Cable Tray in Industrial and Commercial Occupancies [PDC 4.3.1.3.7]

3.3.4.18 Requirement: Control cables shall be multi-conductor and color coded in accordance with the standard industrial practices. Supports Function 2.1.1.

Basis: This requirement is based on standard industrial practices and standards. [PDC 4.3.1.3.9]

3.3.4.19 Requirement: The DC power system shall be used as needed for emergency and normal power $12.47 \mathrm{kV}$ and $4.16 \mathrm{kV}$ switchgear control power. Supports Function 2.1.1. 
Basis: This requirement defines the facility medium voltage switchgear control voltage. The DC power will be available even in a loss of normal power. This improves the reliability of circuit breaker control and is in accordance with good engineering practice. [PDC 4.3.1.1.6]

3.3.4.20 Requirement: The $12.47 \mathrm{kV}$ power output from the main transformer shall be connected to the $12.47 \mathrm{kV}$ main switchgear buses in the $12.47 \mathrm{kV}$ switchgear facility via underground duct banks or an overhead non-segregated phase bus. Supports Function 2.1.1

Basis: This requirement defines the method of power line connection in accordance with good engineering practice. [PDC 4.3.3.5]

\subsubsection{Instrumentation and Control}

Instrumentation and control design details for the system shall be established as the design proceeds.

\subsubsection{Computer Hardware and Software}

There are no computer hardware and software requirements currently established for the electrical power system.

\subsubsection{Fire Protection}

Fire protection requirements for the design of the system are tied to the facility that houses the system's components. These requirements are found in one of the site fire hazards analyses.

The fire protection requirements for outdoor oil-filled transformers, if needed, will be developed as the design progresses.

3.3.7.1 Requirement: Combustible vegetation shall be kept a minimum of 33 feet from electrical power system components and structures.

Basis: This requirement satisfies the site fire hazards analysis. [Site Fire Hazard Analysis (BSC 2004a)]

\subsection{TESTING AND MAINTENANCE REQUIREMENTS AND BASES}

\subsubsection{Testability}

The design requirements for testability of equipment and components shall be included in this section as the design matures, and as the specification for such equipment and components are available to the project.

\subsubsection{TSR -Required Surveillances}

This system is non-SC and is not subject to TSR. 


\subsubsection{Non-TSR Inspections and Testing}

Non-TSR inspection testing shall be included in this section as the design matures. This section shall include the required inspection, acceptance criteria, and other features to facilitate surveillance actions.

\subsubsection{Maintenance}

The electrical power system maintenance activities to comply with the manufacturer recommendations shall be developed as needed. As the design matures, this section shall include manufacturer recommendations and periodic maintenance schedules to ensure continued reliability.

\subsection{OTHER REQUIREMENTS AND BASES}

\subsubsection{Security and Special Nuclear Material (SNM) Protection}

Security and SNM Protection requirements for the electrical power system design shall be developed if required by the results of the vulnerability assessment. However, due to the sensitivity issues of the subject, a separate SDD shall be issued to the project and only to personnel with proper clearance.

\subsubsection{Special Installation Requirements}

Special installation requirements for major electrical equipment shall be included in this section as the design matures, and shall include physical separation requirements, specific cable usage and routing, proper safety clearances, and maintenance accessibility.

\subsubsection{Reliability, Availability, and Preferred Failure Modes}

There are no unique requirements for system reliability or availability. There are several system mission requirements contained in Section 3.1.1.3, which support system availability and reliability. These include the use of preferred and alternate utility supplies, the standby and emergency power subsystems and UPSs. The system is non-SC and therefore does not have a preferred failure mode. As the design matures, this section shall include provisions to improve reliability, such as equipment redundancy, diversity, physical separation, electrical isolation and other features designed for early detection of component failures.

\subsubsection{Quality Assurance}

The electrical power system is non-SC and is not subject to the requirements of the quality assurance program described in Quality Assurance Requirements and Description (DOE 2004).

\subsubsection{Miscellaneous Requirements}

There are no miscellaneous requirements at this time. 


\section{SYSTEM DESCRIPTION}

\subsection{CONFIGURATION INFORMATION}

\subsubsection{Description of System, Subsystems, and Major Components}

\subsubsection{Description of the System}

The electrical power system designed for the repository facility is a reliable and robust system. The system is designed to regulate utilization voltages between plus and minus 10 percent (Section 3.1.1.4.1).

As shown in Figure 4-1 the system is designed such that either one of the two utility power supplies to the two switchgear buses can be selected to supply both buses through a closed tie circuit breaker. The design for the repository facility provides for a preferred supply ( $230 \mathrm{kV}$ transmission line), and an alternate supply (138 kV transmission line) (Section 3.1.1.3.2). The $230 \mathrm{kV}$ line supplies power to the entire repository's facility through a step-down transformer to $12.47 \mathrm{kV}$ main switchgear buses through a closed tie circuit breaker. When the $230 \mathrm{kV}$ line becomes unavailable the facility load will manually be transferred to the $138 \mathrm{kV}$ line which will power selected loads on the $12.47 \mathrm{kV}$ buses through a step-down transformer until such time that the $230 \mathrm{kV}$ line becomes available, at which time the facility load will be manually transferred back to the $230 \mathrm{kV}$ source. For added system reliability, standby diesel generators on $12.47 \mathrm{kV}$ main switchgear buses A and B will automatically start and will be available to supply power to selected loads in case of total loss of both offsite sources $230 \mathrm{kV}$ and $138 \mathrm{kV}$.

The electrical power system consists of the following subsystems:

- Switchyard and Standby Power Subsystem

- Normal Power Subsystem

- Emergency Power Subsystem (Section 3.1.1.3.1). 

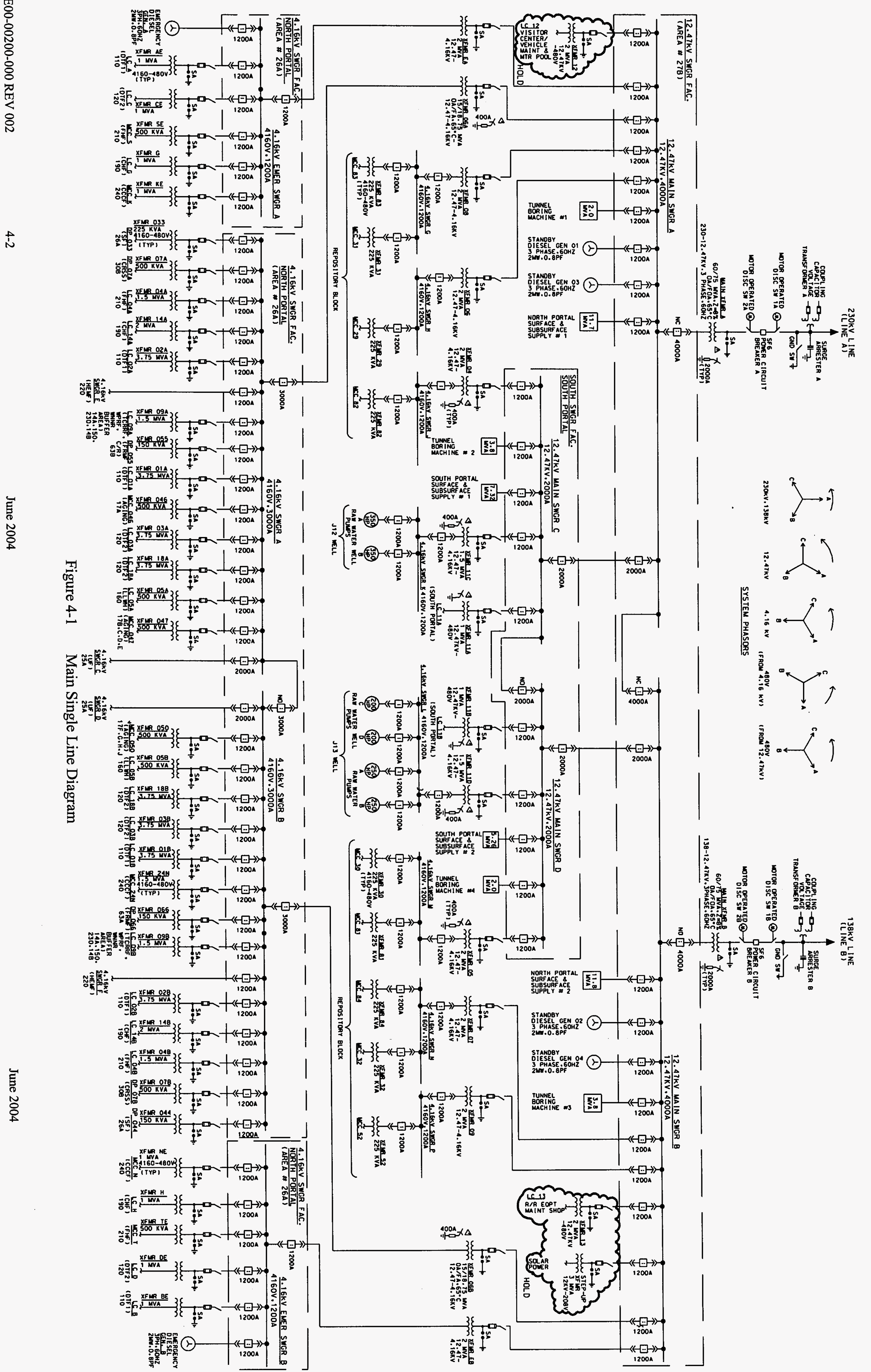


\subsubsection{Description of Switchyard and Standby Power Subsystem}

The switchyard and standby power subsystem starts with the high voltage overhead transmission lines entering the facility at $230 \mathrm{kV}$ and $138 \mathrm{kV}$ supplied by the electrical power utility company, down through their respective main transformers transforming the voltage down to $12.47 \mathrm{kV}$, and then through the $12.47 \mathrm{kV}$ main switchgear buses for distribution to all major areas of the repository facility.

As shown in Figure 4-2, the $230 \mathrm{kV}$ and $138 \mathrm{kV}$ transmission power lines use similar components and connections at the switchyard. The switchyard is fenced and has a locked gate to assure access by authorized personnel only (Section 3.1.1.4.3). Both the $230 \mathrm{kV}$ and $138 \mathrm{kV}$ overhead power lines connect to their respective line sides of the motor disconnect switches and the overhead ground cables connect to the switchyard grounding system. On the line side connections before the disconnect switches, current and potential transformers are connected for voltage monitoring and utility metering. Also at this point, lightning arrestors are installed for protection against lightning strikes. The load side of the disconnect switches connect to the line side of the high voltage power circuit breakers. From the load side of the circuit breakers, a second motor disconnect switch is connected for total isolation of the circuit breaker. From the second disconnect switch, cables connect to the main transformers that are rated at $230-12.47 \mathrm{kV}$ $(138-12.47 \mathrm{kV}), 3$ phase, $60 \mathrm{~Hz}$, oil air/forced air, $65^{\circ} \mathrm{C}\left(149^{\circ} \mathrm{F}\right)$. Also at the same points, surge arresters are provided for protection against high voltage surges. Adequate system protection is provided by protective relays, which will trip the high voltage power circuit breakers and isolate the transmission line circuits under varying electrical fault conditions and parameters, and also sound alarms locally and in the Central Control Center facility.

Inside the switchyard, the $12.47 \mathrm{kV}$ switchgear facility houses the two switchgear buses rated at $12.47 \mathrm{kV}$. All facility loads are designated as group A or group B loads to provide for a reasonable balance between groups (Section 3.1.1.4.2). The $12.47 \mathrm{kV}$ switchgear facility is a temperature controlled environment facility to ensure functionality of electrical components that are sensitive to extreme temperatures. The $12.47 \mathrm{kV}$ power supply from the secondary side of each of the main transformers " $\mathrm{A}$ " and " $\mathrm{B}$ " is connected to the $12.47 \mathrm{kV}$ main switchgear " $\mathrm{A}$ " and " $\mathrm{B}$ " incoming circuit breakers, respectively, by means of underground duct banks or an overhead non-segregated phase bus (Section 3.3.4.20). Power distribution cable routing from the $12.47 \mathrm{kV}$ main switchgear buses is by underground duct banks for nearby facilities in the North Portal, BOP, and to the subsurface entrance. Power distribution is by overhead transmission lines to distant facilities of the South Portal, South Portal subsurface, ventilation shaft areas, and North Construction Portal. The $12.47 \mathrm{kV}$ switchgear bus control power is supplied from the DC power system to allow for breaker operation during a "dead-bus" condition (Section 3.3.4.19).

The standby power sub-system provides power to normal buses in the event that the offsite preferred power supply is unavailable. The standby diesel generators are connected to the 12.47 $\mathrm{kV}$ main switchgear buses to supply power to selected loads. Upon receipt of the loss of voltage signal, the standby diesel generators start and come up to rated speed and voltage (Section 3.1.1.3.8). The SDGs will than be available to supply power to selected loads on the $12.47 \mathrm{kV}$ main switchgear. The standby diesel generator units can be manually started and stopped locally or from the Central Control Center Facility. The standby diesel generators are wye-connected, 
high-resistance grounded and rated at $12.47 \mathrm{kV}, 3$-phase, $60 \mathrm{~Hz}$. The $12.47 \mathrm{kV}$ main switchgear supply the power generated by the standby diesel generators to selected loads. There are four standby diesel generators, two connected to each $12.47 \mathrm{kV}$ main switchgear bus. The standby diesel generator units connected to each bus will be started in sequence. After the first diesel generator is connected, facility load will be added to the $12.47 \mathrm{kV}$ switchgear bus to load the connected diesel generator. Each subsequent diesel generator will then be connected to the 12.47 $\mathrm{kV}$ bus through an automatic synchronizing unit to share loading. More facility load will then be added to the $12.47 \mathrm{kV}$ main switchgear until all of the diesel generators are connected. 


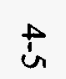

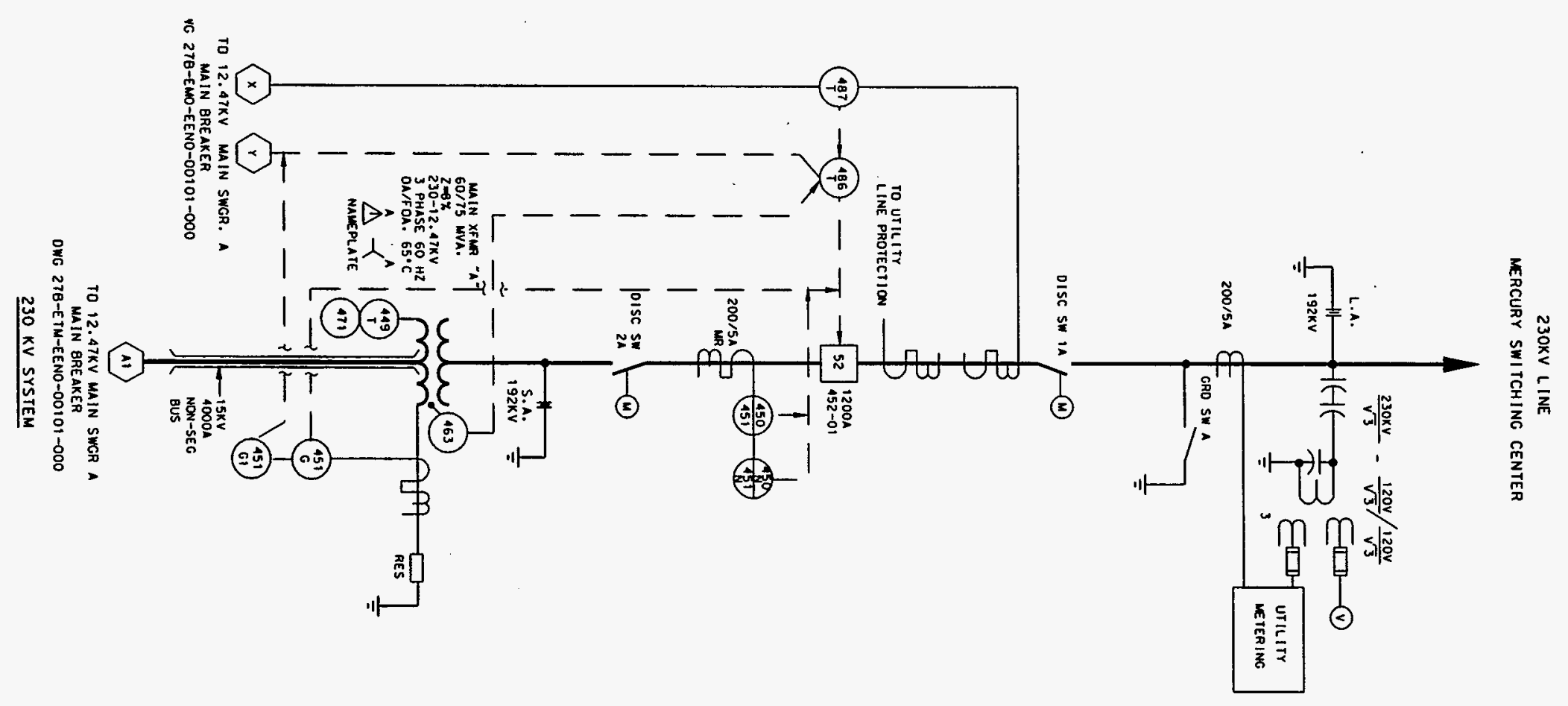

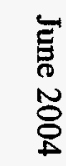
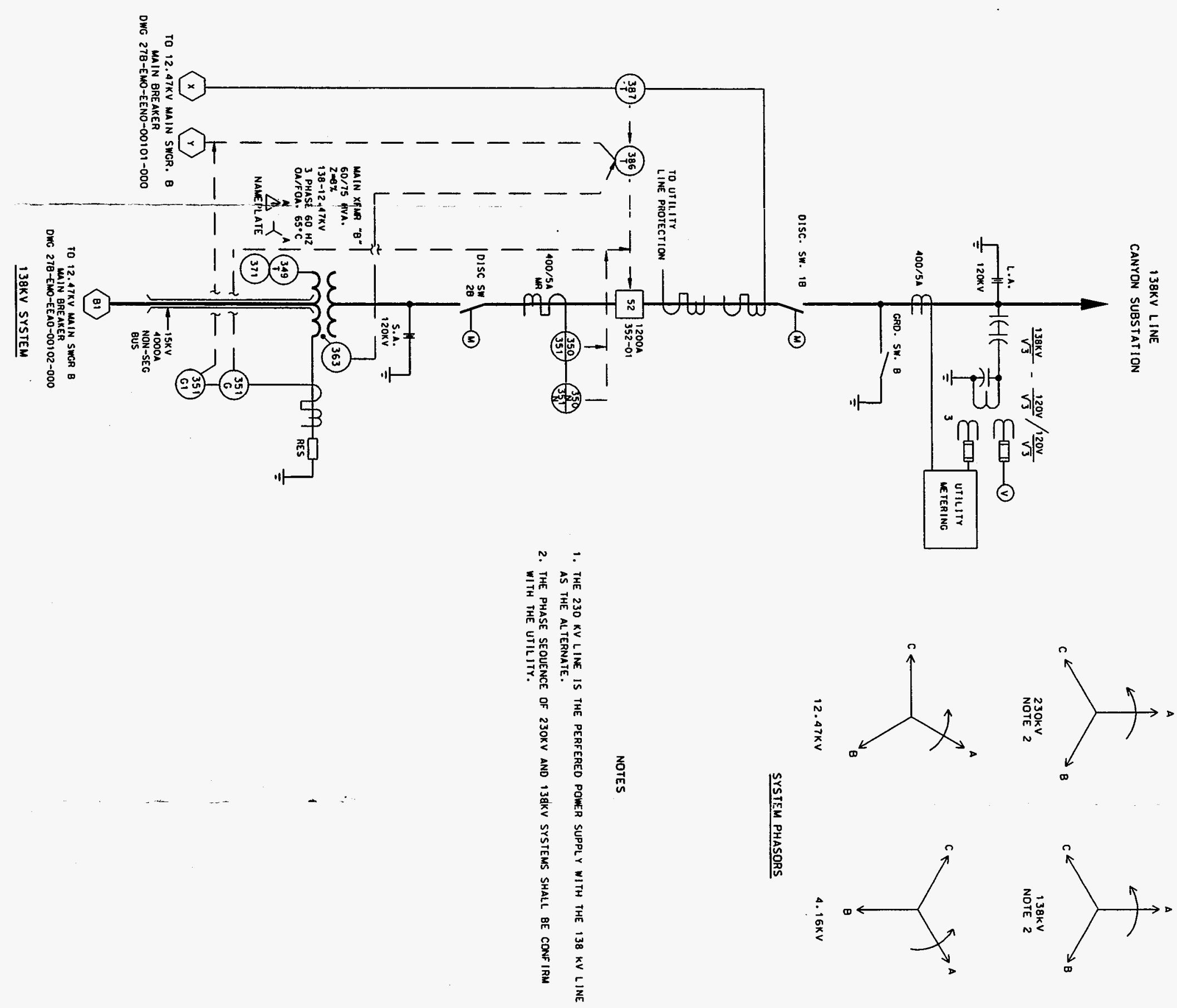


\subsubsection{Description of Normal Power Subsystem}

The normal power subsystem starts from the two $12.47 \mathrm{kV}$ main switchgear buses " $\mathrm{A}$ " and " $\mathrm{B}$ " in the $12.47 \mathrm{kV}$ switchgear facility. Power distribution from the $12.47 \mathrm{kV}$ main switchgears " $\mathrm{A}$ " and " $B$ " supply the normal power to the North Portal facilities, South Portal facilities, BOP facilities, North Construction Portal, and the shaft ventilation areas. As shown in figure 4-1, power from the $12.47 \mathrm{kV}$ switchgear facility is distributed to transformers for a voltage output of $4.16 \mathrm{kV}$ and $480 \mathrm{~V}$ service. The $480 \mathrm{~V}$ load center distributes down to the MCC for further distribution to smaller loads at $277 \mathrm{~V}, 208 \mathrm{~V}$ or $120 \mathrm{~V}$.

The $12.47 \mathrm{kV}$ switchgear feeder circuit breakers are stored energy, draw-out type circuit breakers, rated at 1,200 A. Each feeder breaker has adequate feeder protection that will trip the breaker on fault current and also send indication or alarm to the central control room monitoring system. The main transformers and the $12.47 \mathrm{kV}$ main switchgear are also protected by differential relays that sense an electrical fault in their zone of protection.

The $12.47 \mathrm{kV}$ power feeds down to distribution transformers of either $4.16 \mathrm{kV}$ or $480 \mathrm{~V}$ for smaller load requirements. The $4.16 \mathrm{kV}$ switchgears in the North Portal and South Portal are designed with a tie-breaker between them, similar to the $12.47 \mathrm{kV}$ switchgear, as mentioned previously, for reliability and availability of service. The $4.16 \mathrm{kV}$ feeder circuit breakers are stored energy, drawout type circuit breakers. The protective relays' functions and monitoring are similar to that of the $12.47 \mathrm{kV}$ switchgear circuit breakers.

The $4.16 \mathrm{kV}$ power generally feeds large motor loads or distribution transformers for voltage outputs to $480 \mathrm{~V}$ system. The $480 \mathrm{~V}$ system consists of load centers that feed the $480 \mathrm{~V}$ motor control centers for small motor loads or other distribution and lighting panels. The $480 \mathrm{~V}$ load center also feeds motor loads larger than $150 \mathrm{Hp}$ and up to $300 \mathrm{Hp}$. The $480 \mathrm{~V}$ MCCs are equipped with molded case circuit breakers, static loads, or removable motor starters to feed motor circuits.

As shown in Figure 4-3, the single line diagram depicts the power distribution from the North Portal inside the subsurface access main tunnel. There are two pairs of this power distribution supplies, one pair coming from North Portal, and the other one pair coming from the South Portal area. As shown in Figure 4-3, several distribution sets comprised of a load break switch, transformer, load center, and MCCs, which are located in cutout side portions of the access main tunnel. Each pair of distribution lines are redundant, so that in case of a loss of power from load group A supply, each distribution set can be switched over to the load group B.

As shown in Figure 4-4, the 125 VDC system consists of a 125 VDC panelboard powered by 480 $\mathrm{VAC}$ from MCC through a rectifier unit and a battery system. The $480 \mathrm{VAC}$ power cable connects to a circuit breaker at the battery charger/rectifier unit. The rectifier section transforms the 480 VAC input to a 125 VDC output to the distribution center. Appropriate protective relays are used to adequately protect the in the charger/rectifier unit. Measuring and indicating instruments are also present for local and/or remote (Central Control Center Facility) locations. The figure 4-4 also shows a 125 VDC system that is fed from the two separate groups of power $\mathrm{A}$ and $\mathrm{B}$. The configuration has an added feature of providing a backup battery charger in case of 
malfunction in either one of the primary chargers. The function of the battery charger is to provide the transformed $125 \mathrm{VDC}$ as well as keeping the set of battery cells fully charged. (Section 3.1.1.3.11).

Figure 4-5 shows the 120 VAC UPS. The UPS inverter unit is supplied from an emergency 480 VAC MCC, where the rectifier converts the output to $125 \mathrm{VDC}$ for compatibility with the DC input from a $125 \mathrm{VDC}$ battery. The $125 \mathrm{VDC}$ goes through the inverter for an output of 120 VAC, which powers the UPS panel. A separate normal $480 \mathrm{VAC}$ supply is shown connected through a voltage regulating transformer (for conditioning the power supply) and then to the static transfer switch unit of the UPS. The system follows a sequence where at the failure of the normal 480 VAC power supply, the 125 VDC power takes over and supplies power (Section 3.1.1.3.11). If the inverter fails, the load is transferred to the alternate $480 \mathrm{VAC}$ through the static transfer switch. A manual bypass "make before break" switch is included in the UPS system panel to allow maintenance on the UPS unit without interrupting the loads on the UPS distribution panel.

The UPS provides uninterruptible power of acceptable quality to important monitoring and control loads, including important computer systems that cannot tolerate a power interruption (Section 3.1.1.3.9). The UPS also supplies important process loads that cannot tolerate a power interruption, such as waste package closure welding units. These units are guaranteed to receive uninterrupted power for 15 minutes following a loss of normal and standby power (Section 3.1.2.1). The UPS units located in for the Dry Transfer Facility, the Fuel Handling Facility, and Canister Handling Facility used to power closure cell welding machines and miscellaneous loads will be powered from the normal power sub-system. The UPS units located in the Central Control Center Facility used to power digital control and management information system equipment and communication equipment will be power from the emergency power sub-system.

The uninterruptible power supply system includes the following equipment

- Uninterruptible power supply units for closure cell welding machines, $480 \mathrm{~V}$ input and $480 \mathrm{~V}$ output. They are located in Dry Transfer Facility 1, Fuel Handling Facility, and Canister Handling Facility.

- Uninterruptible power supply units, for digital control management information system and other instrumentation radiation monitoring, $480 \mathrm{~V}$ input and 208/120 V output. They are located in the Central Control Center Facility, Dry Transfer Facility 1, Fuel Handling Facility, and Canister Handling Facility.

- Uninterruptible power supply units for the Communication System, $480 \mathrm{~V}$ input and 208/120 V output. It is located in the Canister Handling Facility, Central Control Center Facility, Dry Transfer Facility 1, and Fuel Handling Facility.

Uninterruptible power supply units for miscellaneous loads. They are located in Dry Transfer Facility 1, Fuel Handling Facility, and Canister Handling Facility. 

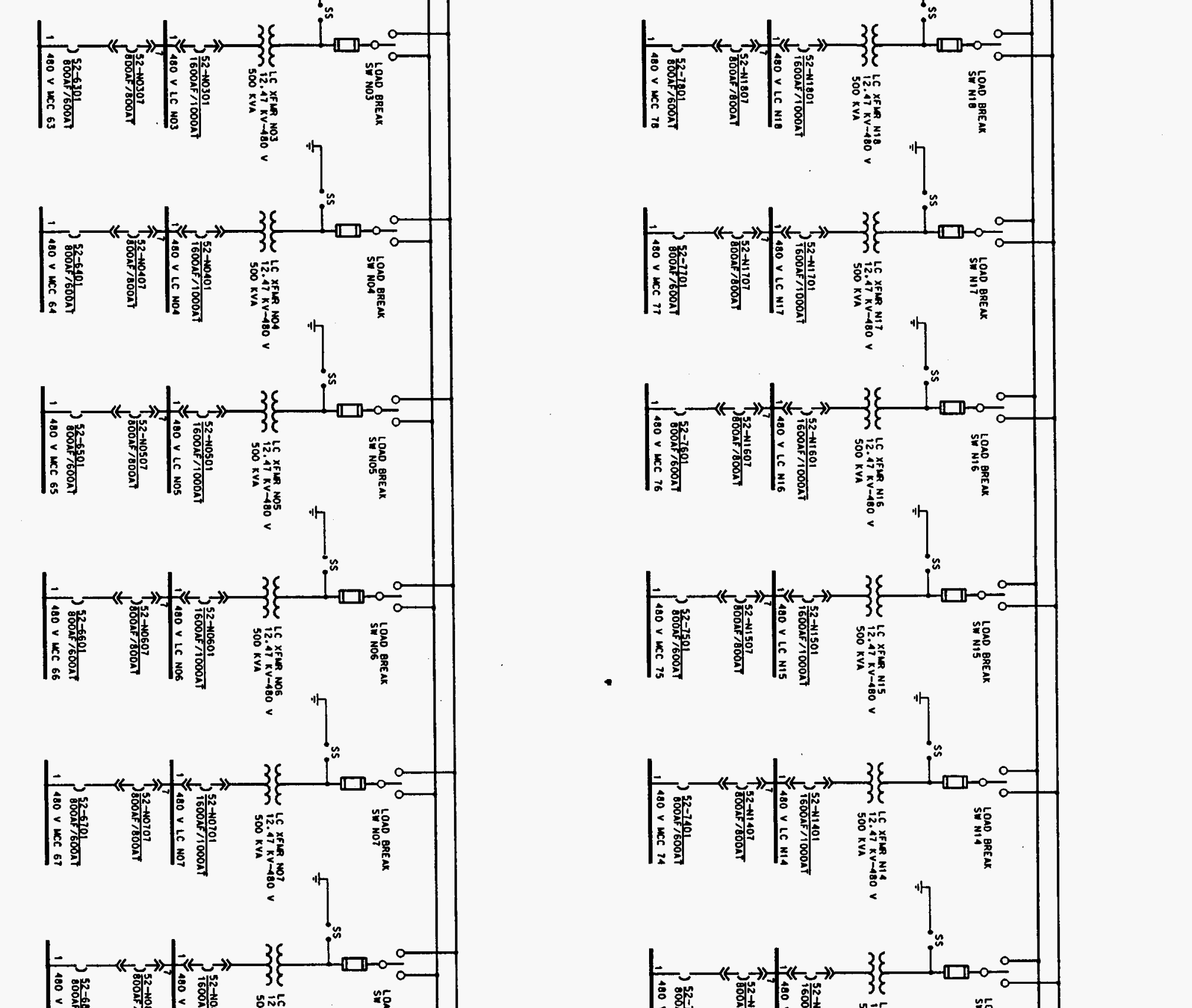

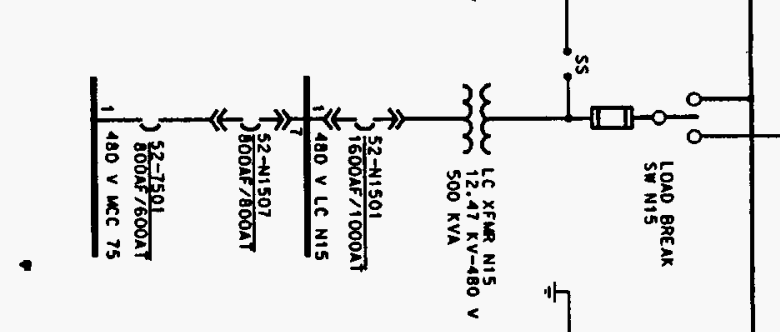
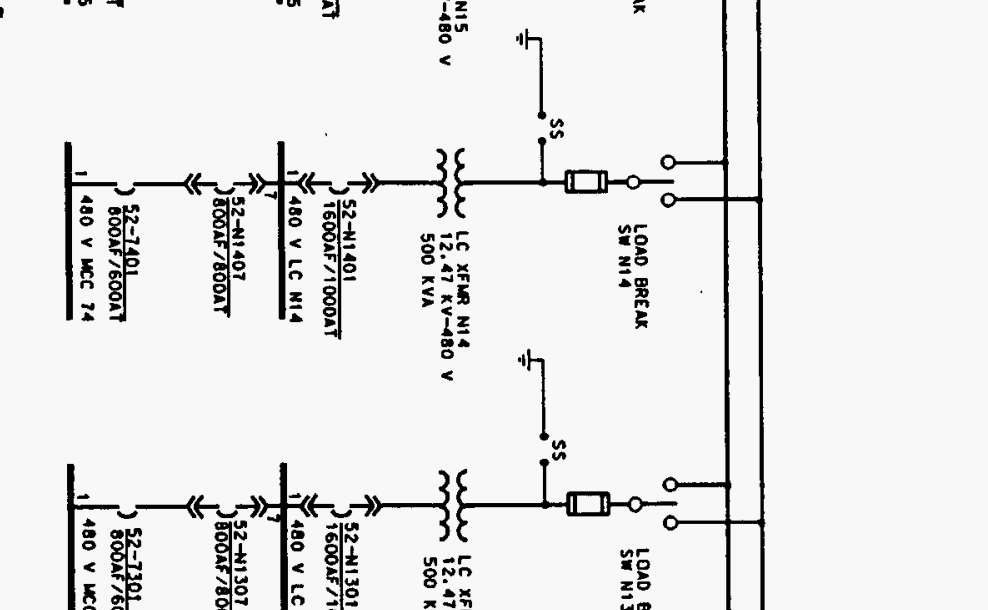


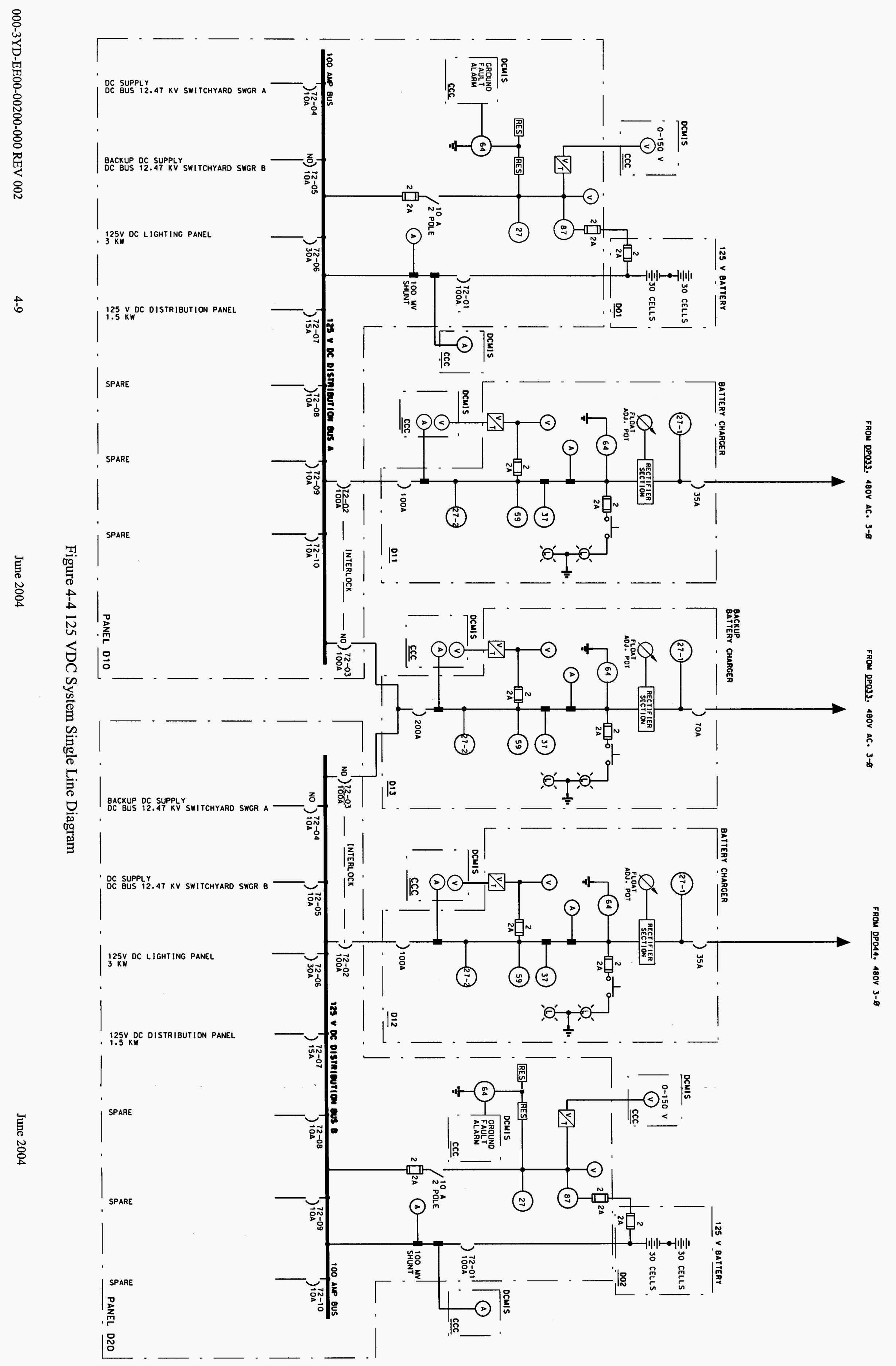




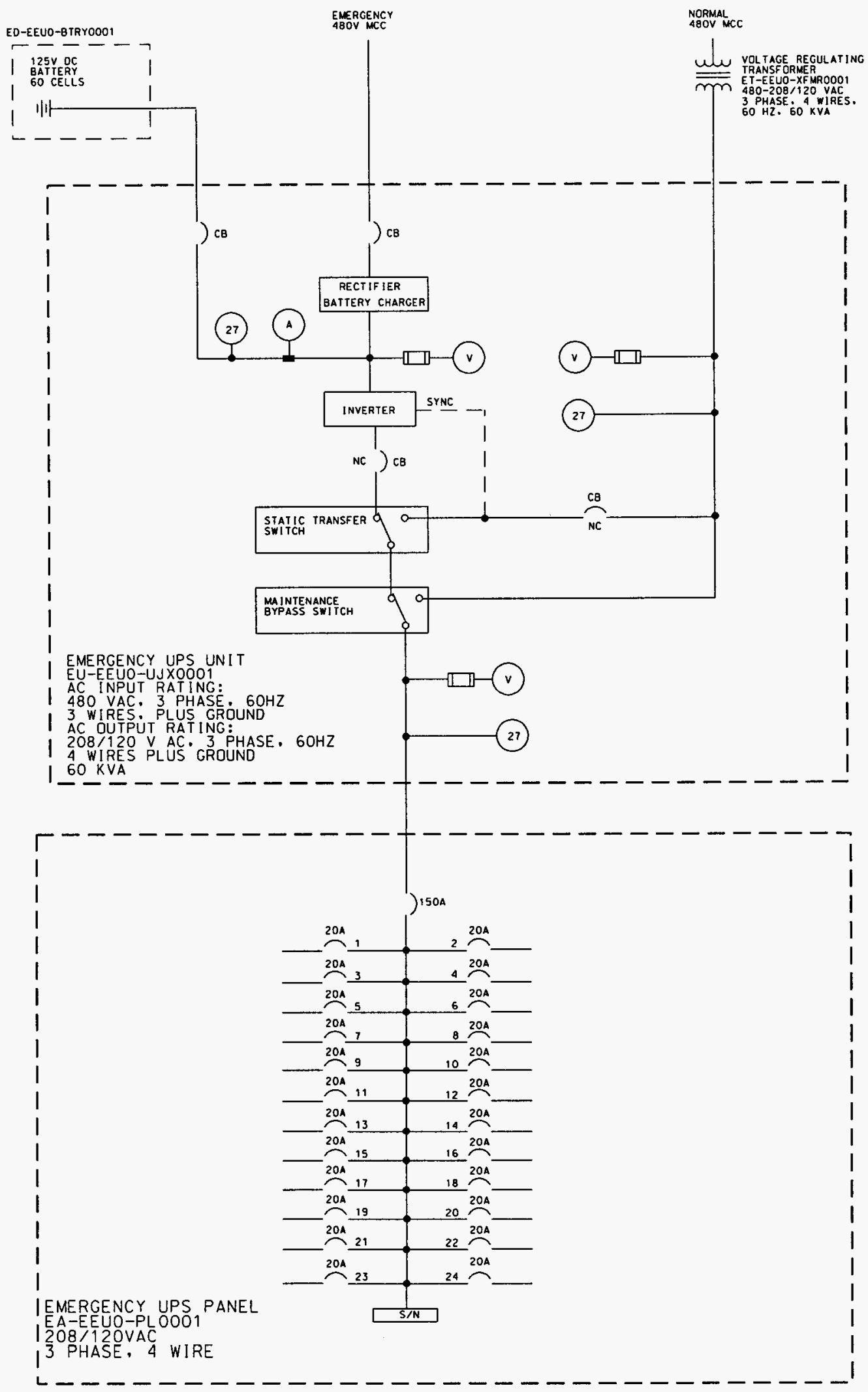

Figure 4-5 Central Control Center Facility, Communication System Emergency UPS 


\subsubsection{Description of Emergency Power Subsystem}

The emergency power subsystem supplies loads essential for the safety of human life, as defined in NFPA 70, Article 700, National Electrical Code, and IEEE Std 446-1995, IEEE Recommended Practice for Emergency and Standby Power Systems for Industrial and Commercial Applications. The loads supplied by the emergency power sub-system are: postevent monitoring system, communications, egress lighting in defined areas, limited select heating ventilation air conditioning (HVAC) units, and worker industrial and life safety systems.

The emergency power subsystem is normally fed by the $12.47 \mathrm{kV}$ normal power in the North Portal area. As shown in Figure 4-1, the normal $12.47 \mathrm{kV}$ feeds down to two $12.47 \mathrm{kv} / 4.16 \mathrm{kV}$ transformers, which supply normal power to the two $4.16 \mathrm{kV}$ emergency switchgear buses. The $4.16 \mathrm{kV}$ emergency switchgears feed all the emergency loads. The $4.16 \mathrm{kV}$ emergency switchgears feed distribution transformers to the $480 \mathrm{~V}$ emergency power system. The load centers distribute down to the MCCs for further distribution to smaller loads at $480 / 277 \mathrm{~V}$ or 208/120 V. The emergency power subsystem DC power is $125 \mathrm{~V}$ (Section 3.1.1.3.7).

Emergency diesel generators, which start automatically, can supply power to their connected $4.16 \mathrm{kV}$ emergency switchgear buses (Section 3.1.1.3.8). The emergency diesel generators are rated at $4.16 \mathrm{kV}, 3$ phase, $60 \mathrm{~Hz}$. The two trains of emergency switchgears are separated physically (located in separate rooms) and electrically (no electrical connection) from each other, in compliance with industry standards. Also, the diesel generators are housed in separate rooms, with fire rated walls between them. The EDGs are connected to the $4.16 \mathrm{kV}$ emergency switchgear buses. The DC feeds for $4.16 \mathrm{kV}$ switchgear control voltage will comply with the separation criteria listed above and will be required to meet the requirements as listed in Section 3.2 of this document.

The 125 VDC batteries and chargers used to supply control power for the $4.16 \mathrm{kV}$ emergency switchgear buses are also a part of the emergency power sub-system. The emergency $125 \mathrm{~V}$ direct current system, located in the $4.16 \mathrm{kV}$ switchgear facility, consists of $125 \mathrm{~V}$ direct current distribution panelboards, $125 \mathrm{~V}$ direct current battery banks, and battery chargers. The emergency battery charger is fed from $480 \mathrm{~V}$ alternating current power source. The power to the $125 \mathrm{~V}$ direct current emergency distribution panelboard is supplied from the $480 \mathrm{~V}$ alternating current motor control center through the emergency battery charger. Relays are incorporated in the design of the battery charger and panelboard to protect the system. Measurement and indication instruments, such as voltmeters and ammeters, are also provided for local monitoring and Central Control Center monitoring. A battery failure, or the $125 \mathrm{~V}$ direct current system failure, is annunciated locally, as well as in the Central Control Center.

\subsubsection{Boundaries and Interfaces}

The electrical power system boundaries start from the fenced switchyard in the North Portal area, cable connections down to the $12.47 \mathrm{kV}$ switchgear facility inside the perimeter fence where the power is distributed from the switchgear circuit breakers to the facilities and extending down to the subsurface power distribution system. The boundary includes the right of way where the overhead transmission lines are routed to the South Portal facilities, cable routing down to the 
subsurface, then up to the cable connections at the ventilation shafts area. In each one of the facilities or areas, the end point of the boundary ends at the load side of the smallest load that requires electrical power. Also included are the connections at the standby diesel generators, the normal power UPS, and the normal power battery system.

The boundaries of the high voltage switchyard start from the $230 \mathrm{kV}$ and $138 \mathrm{kV}$ transmission lines terminating at the motor disconnect switch, current transformer, potential transformers and at the lightning arresters. The boundaries end at the interface point outside the various facilities.

The boundaries of the emergency power system start at the incoming circuit breaker of the 4.16 $\mathrm{kV}$ emergency switchgears down to and including the load centers and then to the MCC connections to the smallest loads that require emergency power. This includes the connections and loads at the UPS, and at the emergency batteries.

\subsubsection{Physical Location and Layout}

Figure 4-6 shows the physical layout of the switchyard, the $4.16 \mathrm{kV}$ switchgear facility and the diesel generator facilities. The fenced area is located at the southwest corner of the North Portal facility.

West of the $4.16 \mathrm{kV}$ switchgear facility, four standby diesel generators are located in-line in Standby Diesel Generator facility. East of the $4.16 \mathrm{kV}$ switchgear facility, two emergency diesel generators are located in the emergency diesel generator facility, separated by a fire-rated wall.

The normal power system physical location is spread throughout the repository facility. The major components of the normal power are the switchyard, the $12.47 \mathrm{kV}$ Switchgear facility, and the $4.16 \mathrm{kV}$ Switchgear facility inside the perimeter fence, as shown in Figure 4-6.

The emergency power system physical location is also spread throughout the repository facility. The major components are shown in Figure 4-6, which are the $4.16 \mathrm{kV}$ emergency switchgear in the $4.16 \mathrm{kV}$ Switchgear facility and the emergency generator facility, which houses the two emergency diesel generators.

Two emergency switchgears are located in the east half of the $4.16 \mathrm{kV}$ Switchgear facility. Emergency power supplied to all facilities in the North Portal is run in underground ductbanks. 

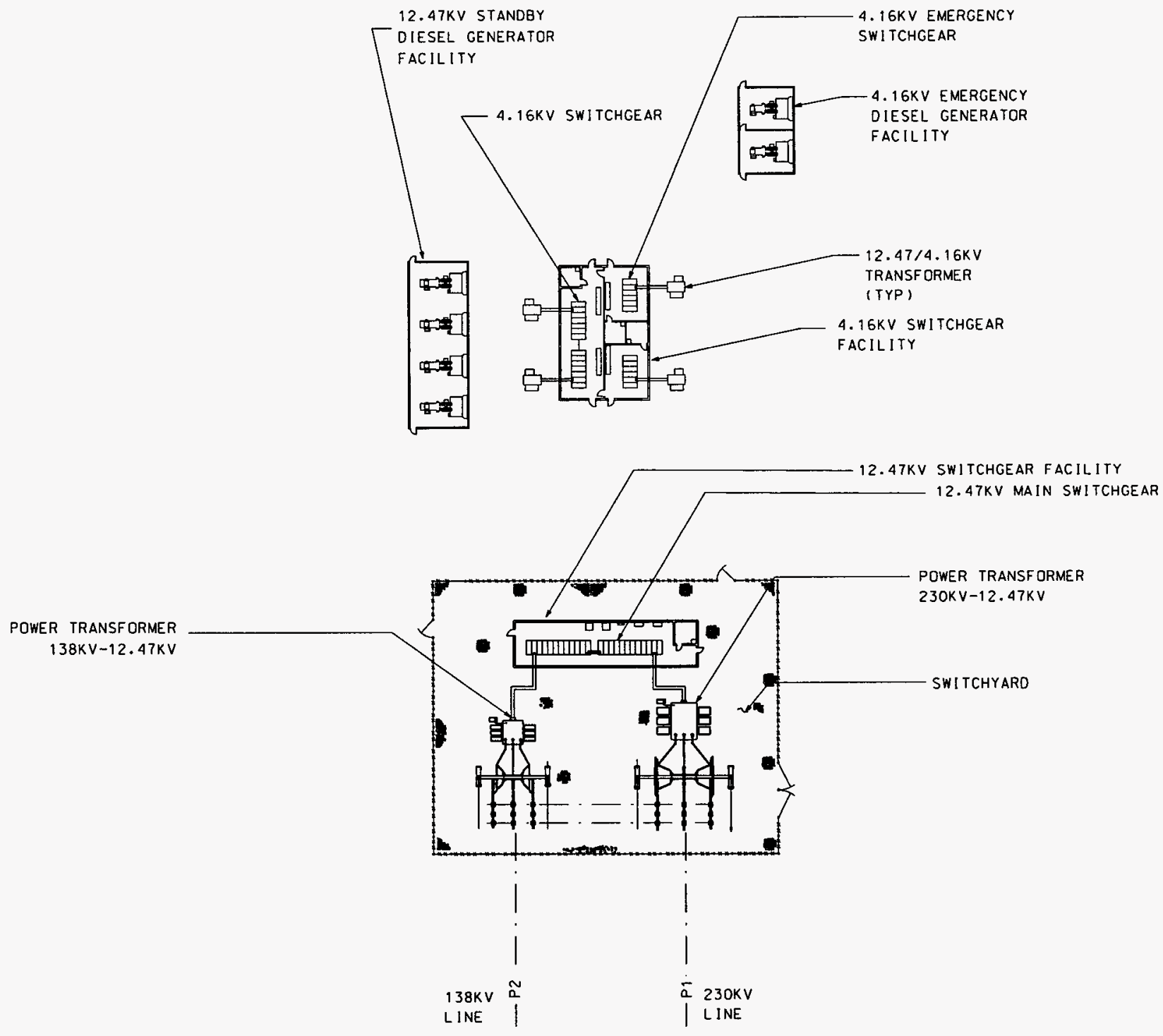

Figure 4-6 12.47 kV Switchgear facility and Diesel Generators, Layout Diagram

\subsubsection{Principles of Operation}

The following section describes the operation of the electrical power system during a loss-ofoffsite power:

Upon loss of both the $230 \mathrm{kV}$ and $138 \mathrm{kV}$ offsite power sources, the emergency and standby diesel generators start automatically. The incoming breaker of the $12.47 \mathrm{kV}$ main switchgear A will be tripped open and all the loads connected to the two $12.47 \mathrm{kV}$ buses will be automatically shed off the buses. After the standby diesel generators have reached their rated voltages and frequencies, they will be manually connected to their respective $12.47 \mathrm{kV}$ main switchgear buses. Once the rated voltage is established at the $12.47 \mathrm{kV}$ main switchgear buses, the Central 
Control Center Facility operator will manually reconnect the selected repository facility loads to their buses.

Similarly, the incoming breakers for the $4.16 \mathrm{kV}$ emergency switchgears will be automatically tripped open and the loads connected to the $4.16 \mathrm{kV}$ emergency switchgear buses will be automatically shed. Once the emergency diesel generators have reached their rated voltages and frequencies, each are automatically connected to their respective deenergized buses. As soon as rated voltage is established at each of the $4.16 \mathrm{kV}$ emergency buses, the loads will manually be sequenced back onto these buses.

In the event that only the $230 \mathrm{kV}$ line is loss, the same operation will still be performed on the $12.47 \mathrm{kV}$ buses. However, instead of connecting the already running standby diesel generators onto the $12.47 \mathrm{kV}$ buses, the $138 \mathrm{kV}$ line will be manually connected to the $12.47 \mathrm{kV}$ buses by manually closing the $138 \mathrm{kV}$ incoming breaker of $12.47 \mathrm{kV}$ main switchgear $\mathrm{B}$. Once voltage is established on the bus, the Central Control Center Facility operator will reconnect the selected critical repository facility loads to their buses and the standby diesel generators will all be shutdown.

At this point in time, the emergency diesel generators have been connected to their respective $4.16 \mathrm{kV}$ emergency buses and already supplying power to the manually sequenced emergency loads. If the CCCF operator determines that the $138 \mathrm{kV}$ line is stable, the operator can perform the transfer of power from the emergency diesel generators back to the $138 \mathrm{kV}$ offsite source. Upon return of the $230 \mathrm{kV}$ source, the CCCF operator will manually perform a load shed of the $12.47 \mathrm{kV}$ main switchgear buses in order to reconnect to the $230 \mathrm{kV}$ preferred power source.

\subsubsection{System Reliability Features}

The electrical power system is very reliable. Two utility feeds (one preferred and one alternate) are used and either feed can supply both $12.47 \mathrm{kV}$ main switchgear buses for further distribution to the site. SDGs are available to backup the utility feeds and are available to support selected loads. EDGs are also provided for the emergency power subsystem loads and are available to support selected loads. Furthermore, uninterruptible power supplies with battery backups are also used to power selected loads.

System reliability is further enhanced by double-end configurations for selected medium and low voltage switchgear.

\subsubsection{System Control Features}

System control features are not available at this stage of the design.

\subsection{OPERATIONS}

\subsubsection{Initial Configuration (Prestartup)}

Operating procedures for this system have not been developed. 


\subsubsection{System Startup}

Operating procedures for this system have not been developed.

\subsubsection{Normal Operations}

Operating procedures for this system have not been developed.

\subsubsection{Off-Normal Operations}

Operating procedures for this system have not been developed.

\subsubsection{System Shutdown}

Operating procedures for this system have not been developed.

\subsubsection{Safety Management Programs and Administrative Controls}

The electrical power system has been subjected to a hazards analysis under the ISM program. Design requirements that satisfy the results of this analysis are included in Section 3.

\subsection{TESTING AND MAINTENANCE}

\subsubsection{Temporary Configurations}

There are no temporary configurations currently identified for this system.

\subsubsection{TSR-Required Surveillances}

The electrical power system is non-SC and not subject to TSRs. No TSR-required surveillances are needed for this system.

\subsubsection{Non-TSR Inspections, and Testing}

The electrical power system contains standard commercial components. These do not require special non-TSR inspections and testing. A test program for the system will be developed using manufacturer recommendations as guidance.

\subsubsection{Maintenance}

Planned maintenance activities (predictive and preventive) for this system have not yet been developed. Manufacturer recommendations will be used as guidance for the preparation of maintenance procedures and the schedule for planned maintenance activities. 


\section{REFERENCES}

\subsection{DOCUMENTS CITED}

BSC (Bechtel SAIC Company) 2003a. Q-List. TDR-MGR-RL-000005 REV 00. Las Vegas, Nevada: Bechtel SAIC Company. ACC: DOC.20030930.0002 (DIRS 165179)

BSC (Bechtel SAIC Company) 2004c. Safety Classification of SSCs and Barriers. CAL-MGRRL-000001 REV 00B. Las Vegas, Nevada: Bechtel SAIC Company. ACC: DOC.20040615.0008 (DIRS 169971)

BSC (Bechtel SAIC Company) 2003c. Preliminary Nuclear Safety Design Bases for License Application. TDR-MGR-RL-000006 REV 00. Las Vegas, Nevada: Bechtel SAIC Company. ACC: DOC.20030930.0008 (DIRS 165182)

Siddoway, D.W. 2003. Project Functional and Operational Requirements. TDR-MGR-ME000003 REV 01. Las Vegas, Nevada: Bechtel SAIC Company. ACC: ENG.20030630.0001. (DIRS 163904)

BSC (Bechtel SAIC Company) 2004a. Site Fire Hazards Analysis. 000-30R-PF00-00100-000 REV 00A. Las Vegas, Nevada: Bechtel SAIC Company. ACC: ENG.20040305.0014. (DIRS 168149)

BSC (Bechtel SAIC Company) 2004b. Preliminary Hazards Analysis for License Application Study. 000-30R-HPYK-00100-000-00A. Las Vegas, Nevada: Bechtel SAIC Company. ACC: ENG.20040610.0002. (DIRS 167313)

Canori, G.F. and Leitner, M.M. 2003. Project Requirements Document. TER-MGR-MD000001 REV 02. Las Vegas, Nevada: Bechtel SAIC Company. ACC: DOC.20031222.0006. (DIRS 166275)

Doraswamy, N. 2004. "Preliminary Draft Input Version of Project Design Criteria Document." Interoffice memorandum from N. Doraswamy (BSC) to Distribution, May 26, 2004, 0526041747, with attachment. ACC: MOL.20040526.0027. TBV-5850 (DIRS 169548)

LP-3.26Q-BSC, Rev. 1, ICN 4. System Description Documents. Washington, D.C.: U.S. Department of Energy, Office of Civilian Radioactive Waste Management. ACC: DOC.20040520.0006. (DIRS 169513)

\subsection{CODES, STANDARDS, REGULATIONS, AND PROCEDURES}

DOE (U.S. Department of Energy) 2004. Quality Assurance Requirements and Description. DOE/RW-0333P, Rev. 14. Washington, D.C.: U.S. Department of Energy, Office of Civilian Radioactive Waste Management. ACC: DOC.20040331.0004 (DIRS 168669) 
DOE-STD-3024-98. 1998. Content of System Design Descriptions. Washington, D.C.: U.S. Department of Energy. TIC: 254659 (DIRS 164472)

IEEE Std 141-1993. 1994. IEEE Recommended Practice for Electrical Power Distribution for Industrial Plants. New York, New York: The Institute of Electrical and Electronics Engineers. TIC: 240362. (DIRS 122242).

IEEE Std 446-1995. 1995. IEEE Recommended Practice for Emergency and Standby Power Systems for Industrial and Commercial Applications. New York, New York: Institute of Electrical and Electronics Engineers. TIC: 242952. (DIRS 125763)

IEEE Std 1202-1991. IEEE Standard for Flame Testing of Cables for Use in Cable Tray in Industrial and Commercial Occupancies. New York, New York: Institute of Electrical and Electronics Engineers. TIC: 253647. (DIRS 160800)

ANSI/IEEE Std 344-1987 (Reaffirmed 1993). IEEE Recommended Practice for Seismic Qualification of Class $1 E$ Equipment for Nuclear Power Generating Stations. New York, New York: American National Standards Institute. TIC: 253538. (DIRS 159619)

ANSI C84.1-1995. 1995. Electric Power Systems and Equipment - Voltage Ratings (60 Hz). Rosslyn, Virginia: National Electrical Manufacturers Association. TIC: 242358 (DIRS 126007)

NFPA 70. 2002. National Electrical Code. 2002 Edition. Quincy, Massachusetts: National Fire Protection Association. TIC: 252084. (DIRS 157764)

10 CFR 63. Energy: Disposal of High-Level Radioactive Wastes in a Geologic Repository at Yucca Mountain, Nevada. Readily available. (DIRS 156605)

\subsection{DATA TRACKING NUMBER}

No source data are cited in this document.

\subsection{SOFTWARE CODES}

No software codes are cited in this document. 
APPENDIX A

GLOSSARY 


\section{APPENDIX A}

\section{GLOSSARY}

Basis

Function

Performance Acceptance Criteria

Requirement
Statements that refer to design requirements for SSCs and identify why the requirement exists, why it is specified in a particular manner, and why a specified value is used. The design bases provide information that identifies the specific functions performed by the SSCs of a facility and the specified range of values chosen for controlling the parameters that are the referenced boundaries for the design of the SSCs.

A function is the statement of the purpose of a system or component.

Performance acceptance criteria are statements that provide the verifiable measures of how well the design specification has been achieved.

A specification of what the design solution must do. Requirement statements should also include a statement of how well the specification is to be achieved so as to permit verification. In some cases, there are several different criteria for measuring the success of the achievement of the specification and these would be listed as performance acceptance criteria. 
APPENDIX B

LIST OF KEY SYSTEM CHARTS, DIAGRAMS, DRAWINGS, AND LISTS 


\section{Appendix B}

The following drawings contain preliminary details on the electrical power distribution system. As always, consult the most recently approved drawing revision, which can be located through the document control system.

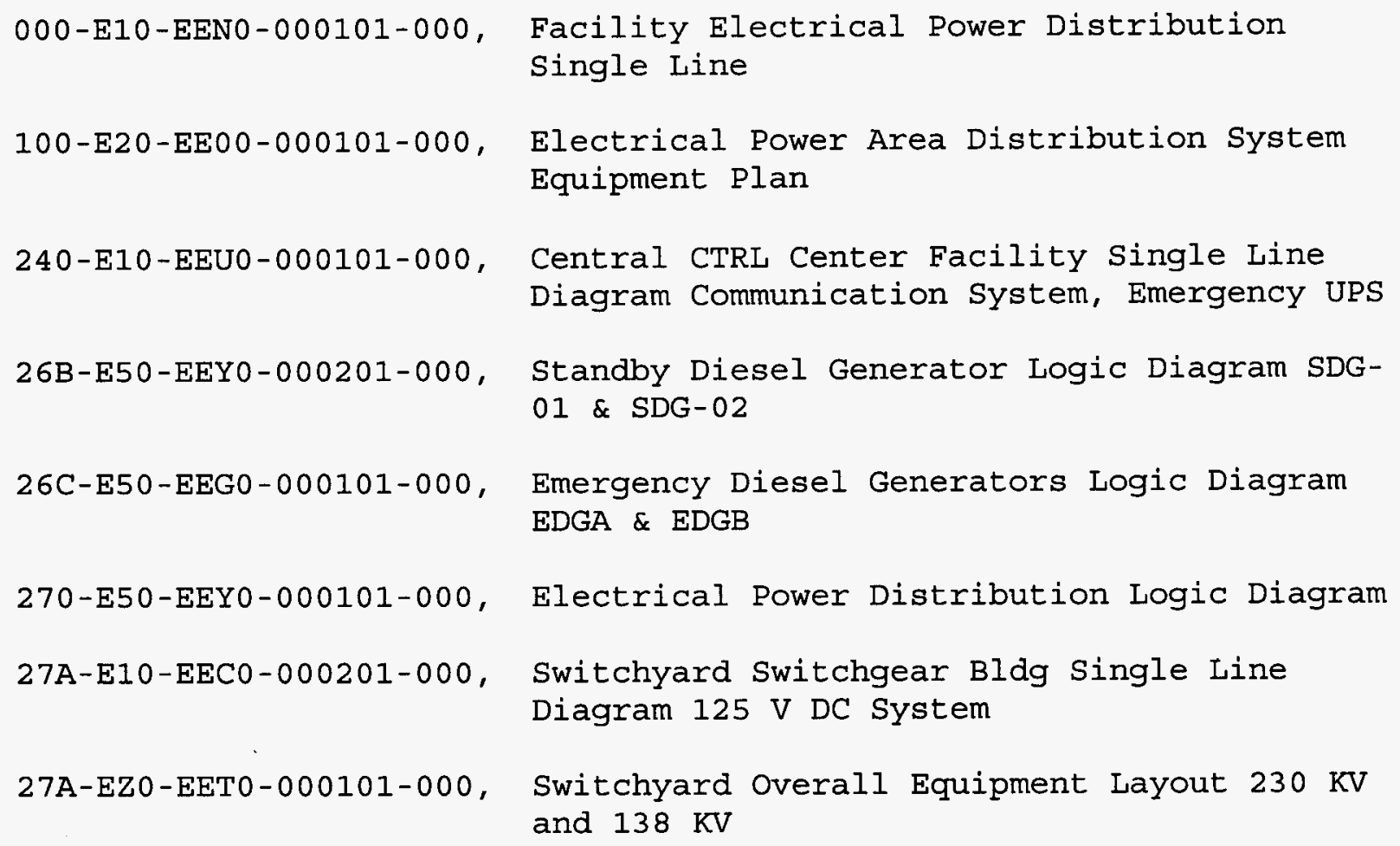


Electrical Power System Description Document

\section{Appendix C}

At this time, there is no list of system procedures. 